\title{
ARTICLE \\ The Lochner era and comparative constitutionalism
}

\author{
Sujit Choudhry*
}

\begin{abstract}
We should be careful to avoid the pitfall of Lochner v. New York which has been described by Professor Tribe... as being "not in judicial intervention to protect 'liberty' but in a misguided understanding of what liberty actually required in the industrial age." The Lochner era gave rise to serious questions about judicial review and the relationship between the court and the legislature....

President Arthur Chaskalson, Constitutional Court of South Africa ${ }^{1}$

I therefore reject the application of the American line of cases that suggest that liberty under the Fourteenth Amendment includes liberty of contract. As I stated earlier these cases have a specific historical context, a context that incorporated into the American jurisprudence certain laissez-faire principles that may not have a corresponding application to the interpretation of the [Canadian] Charter [of Rights and Freedoms] in the present day.
\end{abstract}

Justice (later Chief Justice) Antonio Lamer, Supreme Court of Canada ${ }^{2}$

\begin{abstract}
* Faculty of Law, University of Toronto. E-mail: sujit.choudhryeutoronto.ca; website: www.law.utoronto.ca/faculty/choudhry. I thank Blake Brown, Roy Lee, and Jo-Anne Pickel for excellent research assistance. Ted Tjaden for invaluable help in securing Supreme Court of Canada facta. Trish McMahon for helpful information, and Bernadette Mount for superb secretarial support. This work was financially supported by the Cecil Wright Foundation and the Connaught Foundation. An earlier version of this paper was presented at the 2001 Annual Meeting of the Law and Society Association in Budapest, the 2002 Annual Meeting of the Law and Society Association in Vancouver, and to audiences at the Witswatersrand University School of Law, and the Faculty of Law, University of Cape Town. I thank Harry Arthurs, Blake Brown, Victor Ferreres Comella, Aeyal Gross, Sarah Harding, Vicki Jackson, Heinz Klug, Ross Kriel, Dan Markel, Christina Murray, Ira Parghi, Michel Rosenfeld, Theunis Roux, David Schneiderman, Kevin Stack, Stu Woolman, the audiences at those presentations, and an anonymous reviewer, for helpful comments, discussions, and questions. All remaining errors are mine. This article builds upon and extends arguments first presented in Sujit Choudhry, Globalization in Search of Justification: Toward a Theory of Comparative Constitutional Interpretation, 74 INO. L.J. 819 (1999).
\end{abstract}

${ }^{1}$ Ferreira v. Levin NO, 1996 (1) BCLR 1, 308 (CC), quoting LAURENCE H. TRIBE, AMERICAN CONSTTtUTIONAL LAW 769 (Foundation Press, 2d ed. 1988).

${ }^{2}$ Reference Re Sections 193 and 195.1(1)(c) of the Criminal Code (Man.). [1990] 1 S.C.R. 1123. 1171 (Can.) [hereinafter Prostitution Reference]. 
The trauma experienced in America as a result of the Lochner case must not bring Israeli law to a standstill. We must, over the course of the years to come, adopt a comprehensive constitutional philosophy....

Chief Justice Aharon Barak, Supreme Court of Israel ${ }^{3}$

\section{Introduction}

Even in the era of globalization, politics within nation-states is still predominantly "politics in the vernacular," stressing the particular features of national political communities. But an awareness of the particular can be sharpened through a process of comparison. In the Indian case, for example, Amartya Sen observes that many nationalist thinkers have sought to identify and distinguish the characteristic features of Indian culture from "the West," a process that is at once "dialectical and largely negative," as a mechanism to strengthen the bonds of the Indian political community. ${ }^{5}$ And the differences thus identified need not be cultural, reflecting instead deep disagreement over the fundamental values underlying a basic structure of political and economic rules and institutions. In this vein, the Federalist Papers argued that some features of comparative constitutional experience were to be avoided by the nascent American republic. ${ }^{6}$ And we should expect to find the invocation of difference, in its various forms, not only across jurisdictions and historical contexts but also across a variety of institutional settings. The constructive use of comparison should figure not just in public debate but in legal argument as well, as a resource both to frame and to interpret formal sources of law, including constitutions.

In this article, I extend this claim by describing a distinctive mode of constitutional argumentation I term "Lochner discourse." The Lochner era exerts a powerful hold over the American constitutional imagination as an example of the dangers of judicial review. As Ronald Dworkin colorfully puts it, Lochner is

\footnotetext{
${ }^{3}$ United Mizrahi Bank Ltd. v. Migdal Cooperative Village, 49 P.D. 221 , ๆ 102 (1995) (unofficial translation), reprinted in LORRAINE E. WEINRIB \& Tsvi KaHANa, GLOBAL CONSTTUTIONALISM 21-102 (Faculty of Law, Univ. of Toronto 1999).

${ }^{4}$ Will Kymlicka, Politics in the Vernacular: Nationalism, Multiculturalism, and Citizanship (Oxford Univ. Press 2001).

${ }^{5}$ Amartya Sen, On Interpreting India's Past, in NaTionalism, Democracy and Development: STATE AND PoLrTiCS IN INDIA 10, 17 (Sugata Bose \& Ayesha Jalal eds., Oxford Univ. Press 1997). Later in this essay, Sen points to the contrast employed by Indian nationalists between Western "materialism" and Indian "spirituality," $I d$. at 35.

${ }^{6}$ ThE Federaust No. 10 (Alexander Hamilton).
} 
the "whipping boy" of American constitutional law. ${ }^{7}$ Indeed, much of the edifice of the last fifty years of American constitutional jurisprudence is a reaction to, a rejection of, and an attempt to avoid a repetition of, the Lochner era. I want to explore a related phenomenon that has received insufficient attention from students of comparative constitutionalism-namely, the role of the Lochner era in constitutional discourse outside of the United States. Instead of serving as a positive model for drafting and construing constitutional provisions, the Lochner era serves as a negative guide to constitutionalism. Lochner lurks as a shadow over liberal democratic constitutionalism, an "aversive" constitutionalism that is framed, in part, by what it is not. ${ }^{8}$ In so doing, the Lochner era stands as perhaps the paradigmatic instance of an "anti-model" of comparative constitutional experience. ${ }^{9}$

I argue that Lochner has three distinct meanings. First, Lochner stands for judicial activism, understood as the constitutionalization of judicial policy preferences; this is the meaning ascribed to Lochner by President Arthur Chaskalson of the Constitutional Court of South Africa, in the context of the interpretation of the constitutional right to liberty. Second, Lochner is synonymous with economic libertarianism; this is the meaning given to Lochner by Chief Justice Antonio Lamer of the Supreme Court of Canada, in a case involving the interpretation of the Canadian analogue of the due process clause. Finally, Lochner represents constitutional crisis. This image of Lochner is invoked by Chief Justice Aharon Barak of the Supreme Court of Israel, on the occasion of that court's assertion of the power of constitutional judicial review. As an illustrative case study, I focus on the interpretive work done by the image of the Lochner era in Canada, during the debates surrounding the adoption of the Canadian Charter of Rights and Freedoms, ${ }^{10}$ and in the jurisprudence and critical commentary that has arisen under that document. Not only has each of Lochner's three meanings figured prominently in Canadian constitutional thought; additionally, Canadian constitutional actors have differed over which aspects of Lochner's legacy are to be avoided.

\footnotetext{
${ }^{7}$ Ronald Dworkin, Freedom's Law: The Moral Reading of the American Constitution 82 (Harvard Univ. Press 1996).

${ }^{8}$ Kim Lane Scheppele, Aspirational and Aversive Constitutionalism: The Case for Studying CrossConstitutional Influence Through Negative Models. I INT'L J. CONST. L. (I•CON) 296 (2003).

${ }^{9}$ Heinz Klug. Model and Anti-Model: The United States Constitution and the "Rise of World Constitutionalism," 2000 WIS. L. Rev. 597 (2000). Bruce Ackerman's recent argument that the American approach to the separation of powers should not be relied on by constitutional framers in other jurisdictions is a case in point of this mode of comparative constitutional analysis. Bruce Ackerman. The New Separation of Powers, 113 HaRv. L. Rev. 633 (2000).

${ }^{10}$ Canadian Charter of Rights and Freedoms. Part I of the Constitution Act. 1982. enacted as Schedule B to the Canada Act 1982 (U.K.), 1982, c.11 [hereinafter Charter].
} 
Although I focus on Canada, Lochner discourse is also present in the constitutional discourse of other jurisdictions, as the introductory quotations make clear. Because of the prevalence of Lochner discourse, the Canadian experience offers lessons for the study of the globalization of the practice of modern constitutionalism. In this context, globalization does not simply mean that the commitment to constitutionalism is now widespread. Rather, it implies, in addition, the reliance on comparative material at all stages in the life cycle of modern constitutions, be it comparative jurisprudence in constitutional interpretation or foreign constitutional texts and experiences in the process of constitution making.

The globalization of the practice of modern constitutionalism has had a dramatic impact on the legal academy, reinvigorating the study of comparative constitutional law. However, despite a burgeoning literature, students of comparative constitutional law have largely failed to address, systematically, questions of methodology-that is, to ask the basic questions of what the point of comparative inquiry is, and how that enterprise is to be undertaken. My strategy in answering these questions is, first, to describe the practice of constitutional actors themselves and, second, to identify the reasons they give for engaging in comparative constitutional argumentation. Lochner discourse illustrates that comparative constitutional experiences can function dialogically, by furnishing narratives of constitutional failure that facilitate and enable constitutional choice. Thus understood, learning across jurisdictions does not simply mean the transplantation and/or adaptation of positive constitutional models. Rather, it further entails the avoidance of negative models or constitutional pathologies, which can serve as foils to highlight the potentially worrisome implications of certain institutional, textual, and interpretive options.

\section{The meaning of the Lochner era in American constitutional thought}

Although Lochner v. New York ${ }^{11}$ involved the invalidation of. a rather narrow piece of legislation-a state law setting the maximum hours of work for bakers - the case has come to define a forty-year period of American constitutional jurisprudence, from $1897^{12}$ to $1937 .^{13}$ During this period, the U.S. Supreme Court struck down close to two hundred state and federal laws regulating a wide variety of market relationships. The most infamous of these

\footnotetext{
11198 U.S. 45 (1905).

12 Allgeyer v. Louisiana, 165 U.S. 578 (1897).

${ }^{13}$ West Coast Hotel Co. v. Parrish, 300 U.S. 379 (1937).
} 
cases concerned laws regulating labor relations. ${ }^{14}$ To be sure, we must be mindful of Charles Warren's well-known and provocative observation that the Lochner-era Court also rejected constitutional challenges to a great deal of socioeconomic legislation. ${ }^{15}$ However, putting this point to one side, the Lochner era was characterized by a judicial resistance to the regulatory. redistributive, and activist state the likes of which the American constitutional system has not since seen.

Even a casual observer of American constitutionalism is struck by the dominant place the Lochner era occupies within contemporary American constitutional thought. There is a massive literature on Lochner and its meaning. Legal historians debate the place of the Lochner era within the evolving practice of American constitutionalism, examining the extent to which it marked a departure from or built upon preexisting constitutional doctrine and discourse, the degree to which the Lochner Court was in keeping or out of step with prevailing political ideologies, and the plausibility of the claim that the post-1937 constitutional settlement marked a return to the principles of the pre-Lochner Court instead of a revolutionary transformation of American constitutional law. ${ }^{16}$ With a handful of exceptions, normative constitutional theorists take the wrongness of Lochner as a fixed point in their accounts of constitutional interpretation and feel compelled to explain why exactly Lochner was in error, and how their theories of judicial review would avoid altogether, or minimize the prospects of, a return to Lochner. It is a standard argumentative trope, for

\footnotetext{
${ }^{14}$ See, e.g., Adkins v. Children's Hospital of the District of Columbia, 261 U.S. 525 (1923) (finding a minimum wage law unconstitutional). Other cases involved, for example. laws that laid down professional licensing requirements in connection with the sale of goods (see, e.g., Louis $\mathrm{K}$. Liggett Co. v. Baldridge. 278 U.S. 105 (1928)) and that regulated contracts of insurance (see, e.g., Allgeyer. 165 U.S. 578).
}

152 Charles Warren, The Supreme Court in UnITED StaTEs History, 1836-1918 (Little, Brown, and Co. 1926).

\footnotetext{
${ }^{16}$ For recent discussions, see, e.g.. Michael Les Benedict. Laissez-Faire and Liberty: A Re-Evaluation of the Meaning and Origins of Laissez-Faire Constitutionalism, 3 LAW \& HIST. REv. 293 (1985); 8 OWEN

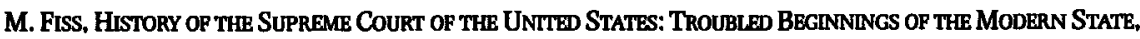
1888-1910 (Macmillan 1993); Howard GLlman, The ConstTiUtion BesifGid: The Rise and Demise Of Lochner Era Police Powers Jurisprudence (Duke Univ. Press 1993); Morton J. Horwitz, The Transformation of American Law. 1870-1960: The Crisis of Legal Orthodoxy (Oxford Univ. Press 1992); Paul Kens, Lochner v. New York: Rehabilitated and Revised, but Still Reviled, 20 J. SUP. CT. HIsT. 31 (1995); Mary Cornelia Porter, Lochner and Company: Revisionism Revisited, in LIBERTY, PROPERTY.

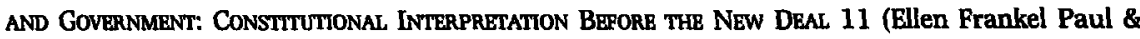
Howard Dickman eds., State Univ. of New York Press 1989); Gary D. Rowe, Lochner Revisionism Revisited, 24 LaW \& Soc. InQuiry 221 (1999); G. EDWARd WhTte, The ConstTtuTion and the New Deal. (Harvard Univ. Press 2000). Bruce Ackerman addresses these historical questions in the context of constructing a theory of the American Constitution in which he emphasizes the revolutionary nature of the turn away from Lochner in 1937. 1 Bruce Ackerman, We tHE People. Foundations (Harvard Univ. Press 1991); 2 Bruce Ackerman, We the People, Transformations (Harvard Univ. Press 1998).
} 
example, for constitutional theorists to proceed from two fixed points: that Brown v. Board of Education ${ }^{17}$ was right, but that Lochner was wrong. ${ }^{18}$ And although Lochner has been long discredited, justices of the U.S. Supreme Court continue to refer to it. ${ }^{19}$ Lochner has been invoked to justify the refusal to recognize certain privacy rights ${ }^{20}$ or to explain that the recognition of certain privacy rights does not raise Lochner's specter. ${ }^{21}$ Indeed, the delegitimization of Lochner is so deeply entrenched that it was explicitly invoked by a plurality of the Court as a reason to scrutinize a redistributive scheme under the takings clause, as opposed to the due process clause, of the Fifth Amendment. ${ }^{22}$ And even in the post-Lochner federalism jurisprudence, members of the Court have cited Lochner to argue that judicial limits on the commerce clause would be unmanageable. ${ }^{23}$

If we sift through American constitutional discourse, though, we find that Lochner entails at least three different meanings, as mentioned earlier. First and foremost, Lochner is synonymous with judicial activism. The focus here is on the Lochner Court's theory of constitutional adjudication, rather than on the substantive theory of political economy animating the Court's jurisprudence.

17347 U.S. 483 (1954).

${ }^{18}$ See, e.g. John Hart ELy, Democracy and Distrust: A Theory of Judiclal Review 65 (Harvard Univ. Press 1980). However, some normative constitutional theorists embrace Lochner (see infra text accompanying notes $61-66)$.

${ }^{19}$ In the context of post-Lochner substantive due process, the Lochner era has been referred to as "deviant" (Washington v. Glucksberg, 521 U.S. 702. 761 (1996) (Souter, J., concurring)), “a treacherous field" (Moore v. City of East Cleveland, 431 U.S. 494, 502 (1977)), and even "threatening... [to] the tranquility and stability of the Nation" (Griswold v. Connecticut. 381 U.S. 479. 522 (1965) (Black, J., dissenting)).

${ }^{20}$ See, e.g. Justice Black's dissent in Griswold. 381 U.S. at 514-15 and 522-24 (charging that the recognition of the right to privacy under a "natural rights" theory of the due process clause amounted to a reinstatement of Lochner-era jurisprudence, because it raised the specter of courts' substituting their own judgments of the wisdom or fairness of public policies for that of legislatures); Justice Rehnquist's dissent in Roe v. Wade, 410 U.S. 113, 174 (1973) (use of compelling state interest in due process clause of the Fourteenth Amendment requires courts to second-guess legislatures in manner of Lochner Court); and Justice Souter's concurrence in Glucksberg, 521 U.S. at 755-89 (rejecting the Lochner Court's "absolutist" protection of liberty under substantive due process in favor of an approach that determines whether the legislature has arrived at a "reasonable resolution of the contending positions," and holding that the criminalization of assisted suicide passed constitutional muster).

${ }^{21}$ See, e.g., Griswold, 381 U.S. at 482 (recognition of a right to privacy does not require the court to sit as "a super-legislature to determine the wisdom, need, and propriety of laws that touch economic problems, business affairs, or social conditions" in the manner of the Lochner Court): Moore. 431 U.S. at 502-3 (distinguishing between the Lochner Court's illegitimate "drawing [of] arbitrary lines" under substantive due process and the reliance on "history" and society's "basic values").

22 Eastern Enterprises v. Apfel. 524 U.S. 498, 537-38 (1998).

${ }^{23}$ United States v. Lopez, 514 U.S. 549, 604-7 (1995) (Souter. J., dissenting). 
Crudely put, the central claim is that the transgression of the judges of the Lochner Court was that, under the guise of constitutional interpretation, they did little more than to impose their own policy preferences on democratically elected legislatures. The Lochner Court, for example, generally held that redressing inequality of bargaining power in labor relations was an impermissible end of governmental regulation. ${ }^{24}$ The interpretation of "liberty" to encompass freedom of contract was also an important doctrinal move. ${ }^{25}$ But the principal tool for the Lochner Court was substantive due process, a constitutional doctrine that American courts fashioned out of the due process clauses of the Fifth and Fourteenth amendments. ${ }^{26}$ Those clauses expressly provide for procedural protection to persons deprived of life, liberty, and property but were interpreted to impose substantive limits on legislation that deprived persons of those interests. ${ }^{27}$ Moreover, as students of comparative federalism are well aware, a narrow interpretation of the commerce clause ${ }^{28}$ played an important supporting role. $^{29}$ The hero for opponents of Lochner's judicial activism is Justice Oliver Wendall Holmes, who famously argued in dissent that "the accident of our finding certain opinions natural and familiar or novel and even shocking ought not to conclude our judgment upon the question whether statutes embodying them conflict with the Constitution." ${ }^{30}$ The identification of Lochner with the constitutionalization of judicial policy preferences is so complete that John Hart Ely coined the term "Lochnering" to capture this idea. ${ }^{31}$ For a judge, "to Lochner" is to commit a cardinal sin.

${ }^{24}$ See. e.g. . Coppage v. Kansas, 236 U.S. 1 (1915). However, the Lochner Court did not apply this principle uniformly. See, e.g., Holden v. Hardy, 169 U.S. 366 (1898); Muller v. Oregon, 208 U.S. 412 (1908).

${ }^{25}$ Allgeyer, 165 U.S. 578 (1897).

${ }^{26}$ U.S. CONST. amends. V, XIV.

${ }^{27}$ See, e.g., Lochner, 198 U.S. 45 (1905) (U.S. CONST. amend. XIV); Adkins v. Children's Hospital of the District of Columbia, 261 U.S. 525 (1923) (U.S. CoNST. amend. V). The origins of substantive due process predate the Lochner era. See, e.g., Dred Scott v. Sanford, 60 U.S. 393 (1856).

${ }^{28}$ U.S. CONST. art. I. $\$ 8$. cl. 3.

${ }^{29}$ See, e.g. Hammer v. Dagenhart, 247 U.S. 251 (1918); Carter v. Carter Coal Co., 298 U.S. 238 (1936); A.L.A. Schechter Poultry Corp. v. United States, 295 U.S. 495 (1935).

${ }^{30}$ Lochner, 198 U.S. at 76 (emphasis added). This passage was quoted with approval by the Court in Ferguson v. Skrupa, 372 U.S. 726, 729-30 (1963), where the Court went on to state:

The doctrine that prevailed in Lochner... and like cases-that due process authorizes courts to hold laws unconstitutional when they believe the legislature has acted unwisely-has long since been discarded. We have returned to the original constitutional proposition that courts do not substitute their social and economic beliefs for the judgment of legislative bodies, who are elected to enact laws.

${ }^{31}$ John Hart Ely. The Wages of Crying Wolf: A Comment on Roe v. Wade. 82 YALB L.J. 920.944 (1973). 
The intellectual source of the critique of Lochner's activism was Legal Realism. A central Realist tenet is rule scepticism. The strong version of rule scepticism claims that formal sources of law (texts, precedents) can never yield determinate answers to particular questions that arise in individual cases before courts of law because of the inherent ambiguities of legal language. The weak version, by contrast, focuses instead on conflicts, gaps, and ambiguities in the system of rules, raising in many cases the basic question of which rule to apply. On either version, the Realists argued that legal forms create the space in which judges may rely on their own preferences, while concealing this possibility from public view by creating the illusion of logical necessity and mechanical application. The result in the Lochner-era case law, as Karl Llewellyn put it, was that "[t]he whole expansion of the due process clause has been an enforcement of the majority's ideal of government-as-it-should be." ${ }^{32}$ The relevant judicial predilection was described variously as involving personal allegiances of class ${ }^{33}$ or substantive views on impugned public policies, the former view being shared by Progressive historians critical of the Lochner Court. ${ }^{34}$ At a descriptive level, the Realist critique culminated in an attack on the distinction between adjudication and legislation and claimed that judges had engaged in the latter under the guise of the former-the claim of "judicial legislation." 35 And as Barry Friedman has vividly demonstrated, the work of Realist academics tracked the broader public criticism of the Lochner Court. ${ }^{36}$

This strand of the Realist critique of Lochner is fundamentally a critique regarding judicial method, and it produced a broad variety of responses. Judicially, the Realists' positive account of the phenomenology of adjudication was married to a normative critique that the Lochner Court had usurped the role of legislatures, which fare far better, both on the dimensions of institutional competence and legitimacy, at determining the substance of socioeconomic regulation. For example, the Lochner Court routinely second-guessed legislative determinations of the costs and benefits of legislation, leading

\footnotetext{
${ }^{32}$ K. N. Llewellyn. The Constitution as an Institution. 34 COLUM. L. REv. 1, 40 (1934).

${ }^{33}$ See, e.g. Felix S. Cohen. Transcendental Nonsense and the Functional Approach, 35 CoLum. L. REv. 809. 845 (1935) ("judges usually reflect the attitudes of their own income class on social questions").

${ }^{34}$ See, e.g. Alfred H. Kelly \& Winfred A. Harbison, The AmErican Constitution: Its Origins and Development 515 (W. W. Norton 1948); Charles G. Haines. The Revival of Natural Law Concepts: A STUDY OF THE ESTABLISHMENT AND OF THE INTERPRETATION OF LIMTTS ON LEGISLATURES WTTH SPECLAL Reference to the Development of Certain Phases of Amerucan Constitutional Law 207, 230-31 (Russell \& Russell 1965); Arnold M. Paul. Conservative Crisis and the Rule of LaW: AtTtTudes of the Bar and Bench, 1887-1895 233-37 (Cornell Univ. Press 1960); Arthur S. Miluer. The Supreme Court and American Captraulsm 58 (Free Press 1968).
}

${ }^{35}$ Benjamin N. Cardozo. The Nature of the Judicial Process 115 (Yale Univ. Press 1921) (describing judicial legislation).

${ }^{36}$ Barry Friedman. The History of the Countermajoritarian Difficulty. Part Three: The Lesson of Lochner, 76 N.Y.U. L. REv. 1383 (2001). 
Justice John Marshall Harlan, in his dissent in Lochner, to argue that the Court lacked the competence to conclude that the health benefits of the challenged law were outweighed by freedom of contract. ${ }^{37}$ Analytically, the move from description to prescription proceeded through an appreciation that judicial "policy analysis" entailed little more than the balancing of competing interests (e.g., rights, welfare, administrative concerns) by courts, in a manner indistinguishable from that undertaken by legislatures. The culmination of the judicial critique of Lochner was a radical restructuring of judicial review, which initially adopted a stance of deference to all government measures not just the socioeconomic policies that were the focus of Lochner-era activism, and predicated judicial review on "a specific prohibition of the Constitution." 38 This attitude of extreme deference was endorsed and defended by the Progressive critics of the Lochner Court. ${ }^{39}$

Intellectually, the Realist critique of constitutional adjudication spawned a variety of contradictory movements. In the postwar era, its principal home in the United States has migrated from law schools to departments of political science. To a generation of political scientists, the Lochner era shattered forever the pretense of an adjudication not influenced or guided by judicial policy preferences. Lochner irreversibly and irredeemably destroyed the boundary between legal and political decision making, thereby throwing into disrepute the very project of constitutional judicial review. Most recently, the Realist torch has been taken up by the behavioralist school of public law scholarship. ${ }^{40}$ These scholars take as their premise the Realist assumption that judges' political preferences, not legal materials, are the best predictor of judicial outcomes, and thus they largely devote their empirical work almost entirely to the former, regarding the study of the latter, for the most part, as a fruitless distraction. ${ }^{41}$

\footnotetext{
${ }^{37}$ Lochner, 198 U.S. at 68-72. The framework employed by the Lochner Court actually made no explicit reference to the weighing of the costs and benefits of government regulation. Rather, the Court stated that what was required was the existence of a "real and substantial" (id. at 64) connection between the objectives of a statute and the means chosen to vindicate those objectives, known as rationality review. However, as Michael Perry has persuasively demonstrated, cost/benefit analysis, as well as the failure of governments to opt for regulatory means that were less intrusive on freedom of contract. were relied on as reasons by the Lochner Court to find that laws failed rationality review. Michaet Perry, The ConstTtution in the Courts: LaW OR Polrtics? 162-64 (Oxford Univ. Press 1994).

${ }^{38}$ United States v. Carolene Products Co., 304 U.S. 144, 152 n.4 (1938).

${ }^{39}$ Learned Hand, The Bul of Rights (Harvard Univ. Press 1958); LaARned Hand. Chief Justice Stone's Concept of the Judicial Function, in THE SPIRTT OF LIBERTY 201, 204 (Knopf 1952).

${ }^{40}$ The leading text is Jefrrey A. Segal \& Harold J. SpaEth, The Supreme Court and the ATtTudinal Model (Cambridge Univ. Press 1993).

41 But see Harold J. Spaeth \& Jeffrey a. Segal, Majorty Rule or Minortty Wul: adherbnce to Preceident on the U.S. Supremi Court (Cambridge Univ. Press 1999).
} 
In the legal academy, the Realist analysis of constitutional adjudication sparked a variety of responses. One was Herbert Wechsler's attempt to identify normative criteria for judicial decision making "that can be framed and tested as an exercise of reason and not merely as an act of willfulness or will," and that also delineate a distinction between legislation and adjudication, his socalled "neutral principles." 42 Another set of responses can be grouped under the heading of what James Fleming aptly terms the "flight from substance." 43 which, I think, refers to two different, but overlapping, strands of theoretical work. One strand consists of accounts of judicial review that require courts to secure the preconditions of representative or deliberative democracy. Ely's representation-reinforcing judicial review is the most famous example of a theory of this sort. ${ }^{44}$ A second strand purports either to deny courts a role, or to minimize their role, in judging the substantive merits of public policy decisions. Well-known examples of these views are Henry Hart and Albert Sacks's Legal Process, with its emphasis on the appropriate institutional division of labor between courts and legislatures; ${ }^{45}$ Alexander Bickel's passive virtues, principally designed to place constitutionally controversial questions before politically accountable decision makers before the questions even come before the courts; ${ }^{46}$ and Cass Sunstein's judicial minimalism, aimed at limiting.both the breadth and depth of constitutional judgments. ${ }^{47}$

Finally, the self-proclaimed descendant of Realism is critical legal studies (CLS). In dramatic contrast to behavioralist political science, CLS takes Realism to task for not taking its descriptive project seriously enough, rather than for taking it too seriously, as the behavioralists have concluded. Instead of terminating the analysis in questions of policy, CLS strives to go further and to identify the conflicting ideologies within which particular policy preferences are nested. ${ }^{48}$ Indeed, both Mark Tushnet and Duncan Kennedy argue that ideology may operate as a real sociological or psychological constraint on judicial policy

${ }^{42}$ Herbert Wechsler, Toward Neutral Principles of Constitutional Law, 73 HARv. L. Rev. 1, 11, 16 (1959).

${ }^{43}$ See generally James E. Fleming. Constructing the Substantive Constitution, 72 TEx. L. REv. 211 (1993): James E. Fleming, Fidelity, Basic Liberties and the Specter of Lochner, 41 WM. \& MARY L. REv. 147 (1999).

${ }^{44}$ ELY, supra note 18.

${ }^{45}$ Henky M. Hart, JR. \& Albert M. Sacks. The legal Process: Basic Problems in the Making and APPLICATION OF LAW (Foundation Press 1994).

${ }^{46}$ Alexander M. Bickel, The Least Dangerous Branch: the Supreme Court at the Bar of Politics (Yale Univ. Press, 2 d ed. 1986).

${ }^{47}$ Ely, supra note 18; Cass R. SunStein, ONe CASE at a Ttme: Judicial Minimalism ON THE Supreme CourT (Harvard Univ. Press 1999).

${ }^{48}$ Mark Tushnet, Critical Legal Studies and Constitutional Law: An Essay in Deconstruction, 36 STAN. L. Rev. 623 (1984). 
choice, because it defines the range of acceptable and unacceptable argument, with Kennedy going so far as to argue that ideology might actually prevent a judge from realizing her preferred policy outcome. ${ }^{49}$ But in a deeply important way, the CLS elaboration of the Realist analysis of adjudication did much more than offer a new perspective on the initial critique of the Lochner Court's activism. It reflected a shift in the very nature of the question raised by Lochner-away from the extent and sources of its alleged activism and toward the identification of the ideology underlying its judgments.

To be sure, this shift predated the rise of CLS. The recasting of Lochner's error was, to a considerable extent, precipitated by a fundamental transformation in the pattern of judicial review in American constitutional law in the 1950s. After a period of deference, not only on matters of socioeconomic policy but also with respect to civil and political liberties, the Court departed from the post-Lochner settlement and began to take an aggressive approach to the protection of the latter. The first flagship decision of the Court's renewed, albeit selective, activism was Brown. This ruling was condemned by the Progressive advocates of judicial deference on the ground that a principled basis could not be found for the selective reinvigoration of judicial review that conferred on some categories of rights a preferred status; the decision was seen as heralding the rebirth of the Lochner era. ${ }^{50}$ As Morton Horowitz wrote, "limiting property rights... was achieved only through a kind of quid pro quo, in effect an agreement on across-the-board constitutional disarmament of the Supreme Court." ${ }^{51}$ The challenge for Brown's defenders, as Owen Fiss put it, was how to "remain attached to Brown and its robust use of the judicial power to further the ideal of equality, yet be happy that Lochner lies dead and buried." ${ }^{52}$ Over a decade later, the site of contestation had shifted to substantive due process itself, which had survived outside the realm of economic rights to protect rights to privacy and decisional autonomy. The case that provoked the most controversy was Roe, with Ely famously equating that decision with the worst excesses of the Lochner period and denouncing the Court for "indulging in sheer acts of will, ramming its personal preferences down the country's throat. ${ }^{n 3}$ As with Brown, Roe required a recasting of Lochner's wrongness.

\footnotetext{
${ }^{49}$ Mark V. Tushnet, Following the Rules Laid Down: A Critique of Interpretivism and Neutral Principles, 96 Harv. L. Rev. 781, 825 (1983); Duncan Kennedy, A Crittoue of Adjudication: Fin de Siècle (Harvard Univ. Press 1997).

${ }^{50}$ See, e.g. HAND, THE BLL OF RJGHTS, supra note 39.

${ }^{51}$ HoRwITZ, supra note 16, at 263.

${ }^{52}$ Fiss, supra note 16 , at 21 .

${ }^{53}$ Ely. supra note 31, at 944. See also Richard A. Epstein. Substantive Due Process by Any Other Name: The Abortion Cases, 1973 Sur. Cr. Rev. 159.
} 
Herein, then, lies Lochner's second meaning-economic libertarianism, or what we would now term, in the context of economic globalization, neoliberalism. The focus of this line of criticism is not Lochner's theory of constitutional adjudication, but Lochner's substantive political theory. This description of the Lochner era posits that the doctrinal categories employed by the Lochner Court reflected and furthered a normative commitment to the principles of freedom of contract and property, and to strict limits on the scope of state intervention in market relations. This is the philosophy of laissez-faire. To reject Lochner, then, is to fight for the ability of the state to redress the inequities and exploitation that arise from the unregulated marketplace. Again, the principal villain is substantive due process, coupled with the interpretation of the liberty interest in the due process clauses to encompass liberty of contract. It was the libertarianism of Lochner that presented significant constitutional obstacles to Roosevelt's New Deal. And the component of the postLochner constitutional settlement of greatest importance has been the decisive and explicit repudiation of the aggressive protection of economic rights, diluting substantive due process protection by recasting rationality review so that socioeconomic legislation almost always passes constitutional muster. ${ }^{54}$

For normative constitutional theorists who are critical of Lochner's economic libertarianism, Lochner's error lay not in its judicial activism but rather in the values with respect to which the Lochner Court was activist. Lawrence Tribe, Michael Dorf, and Ronald Dworkin, for example, have argued that what was wrong with the Lochner Court was not its appeal to political philosophy per se to aid in the construction of the Bill of Rights, but rather its appeal to the wrong political philosophy. ${ }^{55}$ Indeed, these theorists hold that substantive value choice by the judiciary is not only desirable, but, in fact, an inescapable feature of constitutional interpretation. Such a position reveals a distinctly postrealist response to "[t]he dilemma of liberal legalism" created by the revival of judicial activism under the Warren Court. ${ }^{56}$ Thus, these scholars have argued that Lochner was wrong, while the post-Lochner Court's substantive due process jurisprudence (Griswold and Roe) is correct because it is based on the right conceptions of individual freedom. The link between constitutional and political theory is most fully worked out in the work of Dworkin. who draws no firm distinction between the two enterprises. Viewed through the lens of anti-Lochnerism, Dworkin's claim is that Lochner's mistake was that it endorsed a libertarian, as opposed to an egalitarian, conception of liberalism.

\footnotetext{
${ }^{54}$ For a review of the rejection of economic due process. see Robert G. McCloskey, Economic Due Process and the Supreme Court: An Exhumation and Reburial, 1962 Sur. Cr. Rev. 34.

${ }^{55}$ Laurence H. Tribe \& Michael C. Dorf, On Reading the Constitution 66 (Harvard Univ. Press 1991): DWORKIN, supra note 7, at 82.

${ }^{56}$ KENNEDY, supra note 49, at 113.
} 
These normative constitutional theorists have been buttressed by recent work in legal history. This is the so-called literature of "Lochner revisionism," whose basic claim is that the Lochner Court was acting not in furtherance of its class or policy preferences but on the basis of a full-blown constitutional theory with roots in the American constitutional tradition. ${ }^{57}$ Howard Gillman best describes this tradition, depicting it as based on a distinction between class or factional legislation, on the one hand, and legislation directed at promoting public welfare, on the other. Thus understood, Lochner was premised on a commitment not to freedom of contract, but to neutrality or equality before the law. Doctrinally, according to Gillman, the focus was not on the infringement of constitutionally protected rights of contract and property but on setting limits on the exercise of public power (e.g., the "police power" of the states). Sunstein's normative twist on this historical argument is that the Lochner Court defined neutrality incorrectly, by taking, as its baseline, common law entitlements of property and contract without acknowledging the realist insight that those rights themselves arise from state action, as opposed to being prepolitical or natural. ${ }^{58}$

However, these are not the only types of antieconomic libertarian responses to Lochner. One could reject both Lochner's political theory and its theory of constitutional adjudication. Indeed, Justice Felix Frankfurter, both a committed New Dealer and the leading advocate of judicial deference on the Warren Court, situated himself with respect to Lochner in this way. ${ }^{59}$ For him, inasmuch as Lochner and the modern privacy jurisprudence both rely on political theories that do not come from the Constitution itself, Lochner and perhaps even Roe would be regarded as mistakes. And these are not the only strange bedfellows that the fear of Lochner has created. Thus, another group of those opposing Lochner rejects its theory of constitutional adjudication but accepts

\footnotetext{
${ }^{57}$ For recent examples and discussions of Lochner revisionism, see Benedict, supra note 16; Fiss, supra note 16; GLLMAN, supra note 16: HoRWIT, supra note 16; Kens, supra note 16; Porter, supra note 16; Rowe. supra note 16: WHITE, supra note 16, at 241-68. For earlier examples of Lochner revisionism, see LOREN P. BETH, The Development of the AMERICAN CONSTTUTION, 1877-1917 (Harper \& Row 1971): David M. Gold, Redfield, Railroads, and Roots of "Laissez-Faire Constitutionalism," 27 AM. J. Legal Hist. 254 (1983): Alan Jones, Thomas M. Cooley and "LaissezFaire Constitutionalism": A Reconsideration, 53 J. AM. Hist. 751 (1967); Charles W. McCurdy, Justice Field and the Jurisprudence of Government-Business Relations: Some Parameters of Laissez Faire Constitutionalism, 1863-1897.61 J. AM. Hist. 970 (1975). For similar arguments presented during the Lochner era, see Max Lerner, The Supreme Court and American Capitalism, 42 YALE L.J. 668 (1933); Edward S. Corwin, Constitution v. Constitutional Theory, 19 AM. Pol. ScI. Rev. 290 (1925). For a trenchant critique of Lochner revisionism. see Friedman, supra note 36.
}

${ }^{58}$ Cass R. Sunstein, Lochner's Legacy, 87 CouvM. L. Rev. 873 (1987). Sunstein's stance is antilibertarian as well, while he seems here (unlike in later work) to endorse Lochner's theory of adjudication.

${ }^{59}$ See, e.g. . his concurrence in American Fed'n of Labor v. American Sash \& Door Co., 335 U.S. 538 (1949) (upholding a legislative ban on union security clauses in collective agreements). 
its political theory. The leading example here is Robert Bork, who has written that Lochner "lives in the law as the symbol, indeed the quintessence, of judicial usurpation of power," ${ }^{60}$ even though he shares, generally, the political sentiments of the Lochner Court. For Bork as well, then, both Roe and Lochner are wrong. Clearly, to be a full-blooded Lochner revivalist requires an acceptance of both Lochner's political theory and its theory of constitutional adjudication. A relatively small group of scholars-Bernard Siegan, ${ }^{61}$ Richard Epstein, ${ }^{62}$ and Steven Macedo ${ }^{63}$ - fall into this last category. Indeed, Epstein is the purest Lochner revivalist of them all, since he argues against the aggressive protection of civil and political liberties - that is. Roe is wrong, but Lochner is right-by giving priority to economic rights in the manner of the Lochner Court.

Finally, Lochner is associated with the constitutional crisis of Roosevelt's New Deal and is synonymous with deep and prolonged conflict between courts and democratically elected or accountable institutions. There is a familiar story here. ${ }^{64}$ The Lochner era came to an end after a clash between the legislative and executive branches, on the one hand, and the judicial branch, on the other, over the constitutionality of the New Deal. Faced with the invalidation of a series of federal New Deal statutes, ${ }^{65}$ and the prospect of the U.S. Supreme Court striking down more, Roosevelt proposed his infamous "Court-packing plan." Under the plan, the membership of the Court could have been increased so that the Lochner majority would eventually be outvoted. The plan was eventually rejected by the Senate. However, in the midst of the controversy over the plan and before it was rejected, the Court fundamentally shifted direction and abandoned much, if not all, of its Lochner-era jurisprudence. ${ }^{66}$

There is some historical dispute over whether the Court-packing plan was the cause of the Court's about face or whether the decision to overrule its earlier case law had been made before the plan was announced, the latter being

${ }^{60}$ Robert H. Bork, The Tempting of America: The Political Seduction of the Law 44 (Free Press 1990).

${ }^{61}$ Bernard H. SiEgan, Economic LIBERTIES AND the ConstTtution (Univ. of Chicago Press 1980).

${ }^{62}$ Richard A. Epstein. Takings: Private Property and the Power of Eminent Domain (Harvard Univ. Press 1985).

${ }^{63}$ StEPhen Macedo, The New Right v. The Constrtution (Cato Institute 1986).

${ }^{64}$ For a good account, see Whuiam E. Leuchtenburg. The Supreme Court Reborn: The Constitutional Revolution in the Age of Roosevelt (Oxford Univ. Press 1995).

${ }^{65}$ See, e.g., Panama Refining Co. v. Ryan, 293 U.S. 388 (1935): A. L. A. Schechter Poultry Corp. v. United States, 295 U.S. 495 (1935); Louisville Joint Stock Land Bank v. Radford, 295 U.S. 555 (1935); Humphrey's Ex'r v. United States, 295 U.S. 602 (1935); United States v. Butler, 297 U.S. 1 (1936): Carter v. Carter Coal Co., 298 U.S. 238 (1936).

${ }^{66}$ West Coast Hotel Co. v. Parrish. 300 U.S. 379 (1937): NLRB v. Jones \& Laughlin Steel Corp. 301 U.S. 1 (1937). 
consistent with a "legalist" account that explains the "switch in time" as a consequence of an evolution of legal doctrine that had begun prior to the Court-packing crisis. Although initial analyses viewed the judgments as a direct response to the plan, ${ }^{67}$ Frankfurter produced documentary proof for the latter position, ${ }^{68}$ the authenticity of which, however, has recently been challenged. ${ }^{69}$ As Friedman notes, "[t]his question is probably unanswerable."70 Whatever the merits of this historians' debate, the constitutional crisis of the 1930s was a searing experience, and it is an important part of the image of the Lochner Court in the American constitutional imagination. Although not framed by reference to the events of 1937, Bickel's passive virtues were clearly designed not only to blunt the countermajoritarian nature of judicial review but also to protect a Court that was only beginning to rebuild its institutional legitimacy at a time when the resistance to Brown raised the specter of mass lawlessness. Writing against the background of the same events, Robert McCloskey approved of the abandonment of economic due process not on the basis of some coherent normative constitutional theory regarding the unimportance of economic rights, or as a result of limited judicial competence with respect to economic policy but because of the need for the Court not to squander its diminished political capital after "the delusions of grandeur that prompted the judicial crusade against the New Deal."71 Indeed, the link between Lochner and constitutional crisis has been expressly made by members of the Court. ${ }^{72}$ For the Court to repeat the mistakes of the Lochner era is to flirt with institutional disaster.

\section{The Lochner era in Canadian constitutional discourse}

\subsection{Due process}

The Lochner era and its multilayered legacy loom large in the Canadian constitutional imagination. Not surprisingly, given the centrality of substantive due process to the jurisprudence of the Lochner Court, the principal site of

\footnotetext{
${ }^{67}$ See, e.g., Merlo John Pusey, The Supreme Court Crisis (Macmillan 1937).

${ }^{68}$ Felix Frankfurter. Mr. Justice Roberts. 104 U. PA. L. Rev. 311 (1955).

${ }^{69}$ Michael Ariens, A Thrice-Told Tale, or Felix the Cat. 107 HARv. L. REv. 620 (1994).

${ }^{70}$ Barry Friedman. The History of the Countermajoritarian Difficulty, Part Four: Law's Politics, 148 U. PA. L. Rev. 971, 976 (2000).

${ }^{71}$ McCloskey, supra note 54, at 60.

${ }^{72}$ In National League of Cities v. Usery, 426 U.S. 833. 868 (1976), in warning his colleagues against imposing restraints on the commerce clause, Justice Brennan stated that the jurisprudence of the Lochner Court "provoked a constitutional crisis" that was "averted" by the Court's reversal of direction. The joint opinion in Planned Parenthood of Southeastern Pennsylvania v. Casey, 505 U.S. 833, 862 (1992) also referred to the Court-packing crisis and the institutional damage that it did to the Court.
} 
engagement has been the Canadian analogue of the due process clause, section 7 of the Charter. ${ }^{73}$ As Michael Stephens has persuasively demonstrated, the drafting of that provision occurred "very much in the shadow of American constitutional history." 74 Moreover, the subsequent interpretation of that provision evinces a similar engagement with America's constitutional past. Upon close examination, both the drafting history of section 7 and its interpretation have invoked the various meanings of Lochner's legacy, drawing different lessons from the Lochner era for Canadian constitutionalism. ${ }^{75}$

\subsubsection{Constitutional drafting}

The earliest proposals for the Charter demonstrated both an awareness of the Lochner era and the challenges it posed to the drafting of a constitutional bill of rights. The origins of the Charter project can be traced to a white paper written by Pierre Trudeau, published in $1968 .^{76}$ In examining the merits of a due process clause for the Canadian Constitution, Trudeau discussed the American experience with substantive due process in some detail. ${ }^{77}$ His emphasis was on the Lochner period of substantive due process, and his analysis negative, referring with obvious disapproval to "minimum wage legislation, laws against child labour, and hours-of-work statutes" as examples of laws struck down by the U.S. Supreme Court and to the use of substantive due process by courts "to review public utility rates set by legislatures or regulatory agencies." ${ }^{78}$ But Trudeau's

\footnotetext{
${ }^{73}$ Section 7 of the Charter provides that "[e]veryone has the right to life. liberty and security of the person and the right not to be deprived thereof except in accordance with the principles of fundamental justice." Charter, supra note $10, \S 7$.

${ }^{74} \mathrm{~K}$. Michael Stephens, Fidelity to Fundamental Justice: An Originalist Construction of Section 7 of the Canadian Charter of Rights and Ereedoms, 13 NAT'L J. ConsT. L. 183, 218 (2002).

${ }^{75}$ The view that section 7 of the Charter was drafted to avoid the dangers of Lochner is supported by other scholars. IAN GREBNE, THE CHARTER OP RuGHTS 146 (James Lorimer \& Co. 1989); Robert E. Hawkins, Interpretivism and Sections $7 \& 15$ of the Canadian Charter of Rights and Freedoms. 22 OTTAWA L. Rev. 275, 290 (1990); Peter W. Hogg, Canada's New Charter of Rights, 32 AM. J. Comp. L. 283, 290 (1984); Alexander Alvaro, Why Property Rights Were Excluded from the Canadian Charter

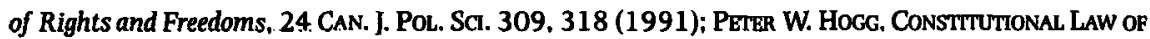
Canada 655 (Carswell, 2d ed. 1985); Peter W. Hogg. Constttutional LaW of Canada 882-83, 886 (Carswell, 3d ed. 1992) (the drafting of section 7 was "intended to banish Lochner from Canada"): John B. Laskin, The Canadian Constitutional Proposals, 1981 PuB. L. 340, 343 n.12; Jean McBean. The Implications of Entrenching Property Rights in Section 7 of the Charter of Rights, 26 ALTA. L. Rev. 548, 568 (1988): Patrick J. Monahan, Polstics and the ConstTtution: The Charter, Federalusm and THE SUPREME Court OF CANADA 76 (Carswell 1987).

76 Pierre E. Trudeau, Can. Dep't of Justice. A Canadian Charter of Human Rights (Queen's Printer 1968) [hereinafter A CANADIAN CHARTER]

${ }^{77}$ Id. at 19-20 (noting that "due process of law" had been given both a procedural and "a substantive interpretation," and that the latter had been relied on to scrutinize "the propriety of all legislation").

${ }^{78}$ Id. at 20.
} 
stance on the other strands of substantive due process was much more positive. Thus, he stated that "[i]n examining American experience with 'due process' it appears that the guarantee as applied to protection of 'life' and personal 'liberty' has been generally satisfactory, whereas substantive due process as applied to 'liberty' of contract and to 'property' has created the most controversy."79

The desire to immunize Canada's Charter from the dangers of Lochner gave rise to two different sets of textual proposals, each taking a different view of what parts of Lochner's legacy were to be avoided. The first set of proposals, which originated in Trudeau's 1968 discussion paper, identified the source of difficulty not as substantive due process per se, but, rather, with its application to economic rights, and accordingly sought to preempt the Lochnerization of the Charter by altering the list of interests protected by due process. Trudeau suggested that while "'life.' personal 'liberty.' and 'security of the person' " would be contained in a "due process" clause, rights of contract and property would not. The first draft of the Charter, dated February 1969, therefore proposed the entrenchment of a provision that protected "the right of the individual to life, and the liberty and security of the person, and the right not to be deprived thereof except by due process of law" 80 but excluded "property" from the ambit of due process protection, hence removing a potential source of economic substantive due process. Moreover, the inclusion of "security" and "of the person" was designed to alter the complexion of liberty, shifting the focus away from economic liberty and freedom of contract and toward corporeal interests, such as bodily integrity.

An explicit link between these textual choices and the desire to avoid Lochner's libertarianism was made clear by Barry Strayer, then-director of constitutional review at the Privy Council Office, who had primary responsibility for drafting the 1969 constitutional proposals. In testimony before the Special Joint Committee of the Senate and the House of Commons on the Constitution (the Molgat-MacGuigan Committee) in 1970, Strayer repeated the government's assessment of Lochner-era jurisprudence:

"Due process" has created problems, particularly under the American Constitution in relation to liberty and property. It has been used at times by the courts to strike down legislation which the majority of Americans apparently regard as being socially desirable. This was particularly true in the first part of the century up until the mid nineteen-thirties.

If one analyzes those cases, it appears that a good deal of the problem has been created by the concept of what is known as substantive due process. The idea [is] that every law can be tested by the court to see

\footnotetext{
${ }^{79}$ Id.

${ }^{80}$ Pierre E. Trudeau, Gov't of Can., Constitution and the People of Canada: An Approach to the Objectives of Confederation, the Rights of People and the Institutions of Government $52 . \S 1$ (e) (Queen's Printer 1969) [hereinafter Constrtution and the People of Canada].
} 
whether it meets certain standards of fairness and that particularly the property rights are adequately protected and the liberty of contracts is adequately protected. It was felt that this was one of the most frequently criticized areas of the American constitutional guarantees and that this was something which could be improved upon in the draft. ${ }^{81}$

He went on to explain that the omission of property and the inclusion of security of the person, in the federal draft, was a deliberate strategy to avoid Lochner-era jurisprudence:

The change attaches the concept of liberty to that of security and relates it to the person. This avoids the problem of the interpretation of liberty which under the American Constitution has been interpreted to include liberty of contract and has been used to strike down legislation which provided for things such as minimum wages and protection against the employment of child labour and this sort of thing. ${ }^{82}$

There is good reason to believe that Trudeau's decision to incorporate the phrase "due process" in the 1969 draft did not reflect a desire to exclude substantive due process entirely. The 1978 federal draft was largely identical and explicitly referred to the desire to avoid the economic limb, but not the privacy/decisional autonomy limb, of substantive due process as the rationale behind the wording of these provisions. ${ }^{83}$ Again, the federal government indicated that the prospect of a Canadian jurisprudence of noneconomic substantive due process "would not necessarily be an undesirable development" because " $[w]$ hen one is dealing with the fundamental rights of life, liberty and security of the individual, it is perhaps appropriate for the courts to concern themselves not only with the procedural fairness of the law but also with its substantive justness." 84 The use of the language of "due process"

813 Canada, Special Jolnt Committee of the Senate and of the House of Commons on the Constitution of Canada, Minutes of Proceeidngs and Evidence of the Special Joint Committee of the Senate and House of Commons on the CONSTTIUTION OF CANADA 15 (June 11, 1970) (Queen's Printer 1970) [hereinafter Molgat-MacGuigan Committee Minutes of Proceedings].

823 id. at 16 (June 11, 1970).

${ }^{83}$ The complete provision can be found in the Constitutional Amendment Bill (Bill C-60) cl. 6 (June 20, 1978), reprinted in 1 ANNE F. BAYkFSKY. CANADA's ConSTITUTION ACT 1982 \& AMENDMENTS: A DOCUMENTARY History 340. 347-48 (McGraw-Hill Ryerson 1989), and was worded as follows:

It is accordingly declared that, in Canada, every individual shall enjoy and continue to enjoy the following fundamental rights and freedoms: ... the right of the individual to life. and to the liberty and security of his or her person, and the right not to be deprived thereof except by due process of law....

${ }^{84}$ Otto E. Lang, Constitutional Reform: Canadian Charter of Rights and Freedoms (Aug. 1978), Address Before Federal-Provincial First Minister's Conference. Ottawa. Ontario (Oct. 30-Nov. 1. 1978), reprinted in 1 BAYEFSKY, supra note 83, at 499.504. 
remained in the numerous federal drafts of the Charter until August 22, $1980 .^{85}$

However, under this first set of proposals, the deliberate omission of property from the due process clause did not mean that those interests were to be left entirely without constitutional protection. Rather, Trudeau's goal was to accord constitutional protection to property interests in a manner that did not open the door to the constitutionalization of laissez-faire. In his 1968 discussion paper, Trudeau had suggested that "specific guarantees of procedural fairness" for "any interference with contracts or property" should be contained outside of the due process clause. ${ }^{86}$ The 1969 draft of the Charter sought to do this by guaranteeing "the right of the individual to the enjoyment of property, and the right not to be deprived thereof except according to law," a degree of constitutional protection thought to be strictly procedural and secured, ironically, by removing any reference to process. ${ }^{87}$ Again, the desire to avoid economic substantive due process through this formulation was made explicit by Strayer in his testimony before the Molgat-MacGuigan Committee:

You will notice that here the guarantee is put in terms of "except according to law" rather than "except by due process of law." This again was to avoid the problem of substantive due process, as the American constitutional lawyers call it, to avoid some sort of external test of fairness being applied to legislation rather than allowing the legislative body to decide on questions of policy...

[T] he American courts have reviewed decisions of bodies which fixed rates for public utilities and have decided whether the rates which the regulating commission has set are sufficiently compensatory for the utility. The court has taken upon itself the power to decide whether the utility is earning enough money. That is an example of substantive due process, and that is the sort of thing which it was hoped could be avoided in this draft. ${ }^{88}$

The 1978 federal proposals altered the protection for property interests somewhat, guaranteeing "the right of the individual to the use and enjoyment of

\footnotetext{
${ }^{85}$ See, e.g., Federal Government's Discussion Draft, Jan. 8, 1979, $§ 10(1)$, reprinted in 2 BAYEFSKY, supra note 83, at 537, 538: Federal Government's Discussion Draft, Oct. 17, 1979, $\$ 6(1)$, reprinted in 2 id. at 574, 575; Federal Government's Discussion Draft. July 4, 1980. $\S 6(1)$, reprinted in 2 id. at 599, 600; Federal Government's Discussion Draft. Aug. 22, 1980, $\S$, reprinted in 2 id. at 669 .

${ }^{86}$ Trudeau, A Canadian Charter, supra note 76, at 20.

${ }^{87}$ Trudeau, Constitution and THe People of Canada, supra note 80, at 52. $\$ 1(\mathrm{f})$. Interestingly, contracts were not accorded any constitutional protection. perhaps because the inclusion of property was regarded as sufficient.
}

883 Molgat-MacGuigan Committee Minutes of Proceedings, supra note 81, at 16-17 (June 11, 1970). 
property, and the right not to be deprived thereof except in accordance with law." 89 However, this provision was also thought to confer strictly procedural protection. Walter Tarnopolsky, a leading constitutional scholar, explained to the 1978 special joint committee on the Constitution of Canada (the Lamontagne-MacGuigan Committee) the probable motivation and effect of this provision, as well as its relationship to the due process clause. He first described the fear of Lochner among both academics and provincial officials:

[T] here has been continuing fear-and I think most of the leading academics and others who oppose a written bill of rights in Canada do so on the basis that they fear the possibility of the Supreme Court introducing the substantive due process interpretation which the American Supreme Court did. A large number of both academic opinion [sic] and other provincial officials who have opposed a written bill of rights have pointed to this as a great danger; so this is one of the reasons why I think the property clause was separated from the life and liberty clause with respect to due process of law..$^{90}$

In elaborating upon this "danger," Tarnopolsky focused on the economic dimension of substantive due process:

[T] he interpretation of the American Supreme Court, starting in about the 1890 s and going down to a decision in 1937, was essentially that if you have the right of the individual to life, liberty and property, and the

${ }^{89}$ The Constitutional Amendment Bill (Bill C-60) $\S 6$ (June 20. 1978), reprinted in 1 BaYbrsky. supra note 83, at 348 .

9012 Canada, Special Jont Committer of the Senate and of the House of Commons on the Consttiution of Canada, Minutes of Prockedings and Evidence of the Spectal Joint Committee of the

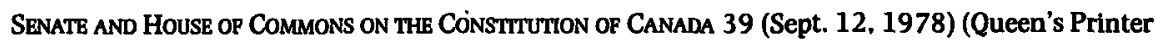
1978) [hereinafter LAMontagne-MaCGUigan Commitree Minutes of Procendings]. Tarnopolsky repeated this description of the opposition to the Charter shortly after its enactment, again invoking Lochner. He wrote that "most of the opposition to the adoption of... Prime Minister Trudeau's proposals to entrench a Charter binding on Parliament and the Legislatures in the written part of our constitution, was based upon the distrust of the judiciary. The fear seemed to be that the Supreme Court would become activist and conservative like the U.S. Supreme Court from 1890 to 1937. introducing a wide substantive due process interpretation...." Walter $S$. Tarnopolsky, The Constitution and Human Rights, in AND No ONE CHEERED: FEDERALISM. DEMOCRACY AND THE CONSTTTUTION ACT 261. 277 (Keith Banting \& Richard Simeon eds., Methuen 1983) (emphasis in original); see also Walter S. Tarnopolsky, The Historical and Constitutional Context of the Proposed Canadian Charter of Rights and Freedoms, 44 L. \& CONTEMr. ProBs., Summer 1998, at 169, 192. A good example of this sort of opposition can be found in the brief submitted by Douglas Schmeiser to the MolgatMacGuigan Committee, see 49 Molgat-MacGuigan Committer Minutes of Prockedings, supra note 81, at 28-57 (Feb. 23, 1971), in which both the activist and libertarian critiques of Lochner figure prominently. Thus, as his example of "Decisions based on Purely Personal Values," Schmeiser gives Lochner. 49 id. at 34. Moreover, his lengthy list of examples of "Bad Judicial Decisions" (a term he does not define) is dominated by Lochner-era case law. 49 id. at 36-39. Interestingly. indicating the extent to which the Lochner era was part of the common understandings underlying the process of constitutional reform, he assumes a great deal of familiarity with the New Deal litigation, stating that those cases "are almost too recent and too familiar to justify rehearsal." 49 id. at 38. 
right not to be deprived thereof except by due process of law, it is an infringement of freedom of contract and an infringement of the right to property for a legislature to provide, for example, that you cannot contract for a wage scale lower than the minimum wage scale. Minimum wage laws clearly contravene, to some extent, freedom of contract.... And it is the same thing with maximum hours and the same thing with restrictions on child labour. All of the various social and economic welfare provisions were held invalid on the basis that they contravened a substantive interpretation of the due process clause. ${ }^{91}$

The second set of proposals sought to avoid both limbs of substantive due process by removing references to "property" and "due process" and replacing the latter with language that unambiguously connoted strictly procedural protection for the interests enumerated therein. Tarnopolsky put forth this idea in testimony before the Molgat-MacGuigan Committee in 1970, proposing "rules of natural justice" or "rules of fundamental justice" as alternatives to "due process." Although he was doubtful that the Canadian judiciary would give a substantive interpretation to a "due process" provision, Tarnopolsky, nonetheless, proposed this language to make the reference to process "much more explicit." 92 This suggestion was incorporated into the Molgat-MacGuigan Committee's report, handed down in 1972, which suggested that the Charter guarantee "[t]he right of the individual person to life, liberty and security of the person, and the right not to be deprived thereof except in accordance with the principles of fundamental justice," 93 a phrase that again, ironically, makes no explicit reference to procedure. ${ }^{94}$ The Committee referred to the Lochner era in support of this proposal:

We should like to avoid the use of the phrase "due process of law" entirely ... because of its unfortunate interpretation in the United States

9112 LaMontagne-MacGuigan Committwe Minutes or Prockedings, supra note 90, at 39 (Sept. 12. 1978). The Lamontagne-MacGuigan Committee ultimately suggested that property rights not be deprived except according to "due process of law," because such language would provide "more satisfactory [i.e., secure] protection." 20 id. at 11 (Oct. 10, 1978).

\footnotetext{
928 Molgat-MacGuigan Committee Minutes of Prockedings, supra note 81, at 19-20 (Nov. 5, 1970). Tarnopolsky repeated this position later on, both in his academic writings (W. S. Tarnopolsky, $A$ Bill of Rights and Future Constitutional Change, 57 CAN. B. REv. 626, 632 (1979)) and in testimony on behalf of the Canadian Civil Liberties Association before the Special Committee of the Senate and of the House of Commons on the Constitution of Canada (the Hays-Joyal Committee) in 1980

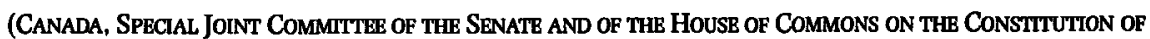
Canada, Minutes of Proceedings and Evidence of the Special Jotnt Committer of this Senate and House of Commons on the Constitution of Canada 7:21 (Nov. 18, 1980) (Queen's Printer 1980) [hereinafter HaYs-Joyal COMMTTtee Minutes of PROCEedings]).

93 Canada, Special Joint COMmitTEe of THe Senatb and of the house of Commons on the Constitution of Canada, Final Report 20 (Information Canada 1972) [hereinafter Molgat-MacGuigan COMMTTTEE REPORT].

${ }^{94}$ The term does appear in a statutory rights-protecting document binding the federal government only, the Canadian Bill of Rights, ch. 44, 1960 S.C. 519 (Can.), reprinted in R.S.C. app. III
} 
under substantive due process. At its worst, this gave judges leeway to substitute their socio-economic views for those of legislatures. ${ }^{95}$

Thus, property received downgraded protection in a separate provision that would have enshrined "[ $t$ ]he right of the individual person to the enjoyment of property, and the right not to be deprived thereof except in accordance with the public good and for just compensation" because the committee thought this language would "allow the maximum latitude for economic decisions by legislatures." 96 But as the federal government noted in its reaction to the report, the provision could have invited the courts to second-guess the propriety of legislation affecting property rights and, hence, would have offered unsure protection against the rise of a Canadian version of Lochner's libertarianism. ${ }^{97}$

In the end, a combination of both sets of textual proposals prevailed. During the summer of 1980 , the federal government engaged in constitutional negotiations with provincial governments, and it came under heavy pressure to drop "due process" from the Charter. John Whyte, the deputy attorney general of Saskatchewan and a constitutional scholar who participated in these discussions, describes in detail how the ghost of Lochner was repeatedly invoked by lawyers representing the provincial governments, to great effect:

Lawyers representing some of the eleven governments raised the concern that courts would read this phrase as guaranteeing substantive due

(1985) (Can.), which came into force in 1960. Section 2(e) guarantees to a person "the right to a fair hearing in accordance with the principles of fundamental justice for the determination of his rights and obligations." Section 2(e) was not specifically referred to by the Molgat-MacGuigan Committee in its final report in 1972 (MOLGAT-MACGUIGAN COMMTTEE REPORT, supra note 93), most likely because the provision had not yet been definitely interpreted by the Supreme Court of Canada. But when the Supreme Court did consider section 2(e), in R. v. Duke, [1972] S.C.R. 917 (Can.), it gave the term a strictly procedural interpretation. In 1981, testifying before the HaysJoyal Committee, federal officials relied on Duke as evidence that section 7 of the Charter would be interpreted in the same way. Testimony of Fred Jordan, Senior Counsel, Public Law, Department of Justice, 46 HAYS-JoyAl COMMITTEE MINUTES OF ProceEdINGS, supra note 92, at 32-33 (Jan. 27, 1981). However, in its first case on the interpretation of section 7, Reference Re Section 94(2) of the Motor Vehicle Act (B.C.). [1985] 2 S.C.R. 486 (Can.), the Supreme Court distinguished Duke, on the grounds that section 2(e)'s explicit reference to "a fair hearing" mandated a strictly procedural interpretation for "the principles of fundamental justice" under the Canadian Bill of Rights. whereas the absence of such language in section 7 meant that Duke was of no assistance in interpreting the Charter.

${ }^{95}$ MOLGAT-MACGUIGAN COMMITTEE REPORT, supra note 93, at 19.

${ }^{96}$ Id. at 20 .

${ }^{97}$ Lang. supra note 84 , at 505. Tarnopolsky, reacting not to this specific proposal but the more general idea of providing some level of substantive protection for property rights, expressed the fear that any such clause would give rise to a bevy of constitutional challenges: he, therefore. recommended that property receive only procedural protection, leaving propertied interests to protect themselves through the legislative process. Tarnopolsky, supra note 92, at 632-33. 
process.... These lawyers could point to the history of the development of substantive due process in American constitutional law as a foreshadowing of the development of a similar expansion of judicial review in Canada beyond what would be necessary for the constitutional protection of minimal procedural standards. Indeed, that history might lead them to apprehend what they consider to be the most sinister form of review of all-review by courts of the ethical propriety of legislation. This somewhat traumatized reading of "due process of law" was fueled by reference to American cases from the first three decades of this century.... In particular, government lawyers brought forth Lochner v. New York to perform its totemic task; the mere mention of the name of the case, which invalidated maximum hours of labour legislation, drove all decent democrats scurrying for language that raised no possibility of substantive review. ${ }^{98}$

The provincial representations were successful. In August 1980, the federal government submitted for consideration what ultimately became the final version of the Canadian due process clause, wherein the phrase "due process" had been replaced by "the principles of fundamental justice." The drafting history shows how this choice was driven by an intention to avoid substantive due process altogether, not merely its economic limb, and to confine section 7 to strictly procedural protection. The best evidence of this intention is the testimony of Strayer, by this time assistant deputy minister of the Department of Justice, to the Special Joint Committee of the Senate and of the House of Commons on the Constitution of Canada (the Hays-Joyal Committee) in 1980. Strayer had primary responsibility for drafting the Charter, and he voiced the imperative to avoid the American experience with substantive due process in its entirety, with reference to both the economic and noneconomic aspects of the jurisprudence:

[I]t was our belief that the words "fundamental justice" would cover the same thing as what is called procedural due process, that is the meaning of due process in relation to requiring fair procedure. However, it in our view does not cover the concept of what is called substantive due process, which would impose substantive requirements as to the policy of the law in question. This has most clearly been demonstrated in the United States in the area of property, but also in other areas such as the right to life. The term due process has been given the broader concept of meaning both the procedure and substance. Natural justice or fundamental justice in our view does not go beyond the procedural requirements of fairness. ${ }^{99}$

\footnotetext{
${ }^{98}$ John D. Whyte. Fundamental Justice: The Scope and Application of Section 7 of the Charter, 13 MAN. L.J. 455, 456-57 (1983).

${ }^{99} 46$ Hays-Joyal Committie Minutes of Prockedings, supra note 92, at 32.
} 
He reiterated that the concern behind the wording of section 7 was to avoid all aspects of substantive due process, referring to the desire to avoid substantive review of infringements of rights of contract and property, ${ }^{100}$ capital punishment, ${ }^{101}$ abortion, ${ }^{102}$ and contraception. ${ }^{103}$ However, it is noteworthy that he gave greater emphasis to the risk of constitutionalizing laissez-faire. Thus, in defending the choice of "fundamental justice" over "due process" he warned members of the committee that "security" could be interpreted broadly to encompass "matters of a...contractual or proprietary nature,"104 and that “' '[l]iberty' at one time in the history of American jurisprudence had been interpreted to cover such things as liberty of contract; and this has been used as the basis for striking down minimum wage laws, because it [sic] contravened liberty of contract." 105 The list of protected interests in the Canadian due process clause omits property, and instead consists of "life, liberty and security of the person." Indeed, property interests are textually absent from the Charter, and as a consequence are without direct constitutional protection. ${ }^{106}$

\footnotetext{
10046 id. at $32,33,36,37$.

10146 id. at 33.

10246 id. at $33,43$.

10346 id. at 43.

10446 id. at 33.

10546 id. at $37,41-42$.
}

${ }^{106}$ The ultimate omission of any express constitutional protection for property rights is a complex story. Until January 8, 1979, as discussed above, the federal proposals called for strictly procedural protection for property. However, the federal government then recast the proposed property clause significantly, by imposing substantive limits on the ability of governments to violate property rights (Federal Government's Discussion Draft, Jan. 8, 1979. $\$ 13$, reprinted in 2 BAYEFSKY, supra note 83, at 539-40). Faced with strong opposition from provincial governments (RoY RoMANOW ET AL.. CANADA ... NotwTthstanding: The Making OF THE ConstTtution, 1976-1982, 44 (Carswell/Methuen 1984)), the property clause was dropped by the federal government in the Federal Government's Discussion Draft, Oct. 17, 1979, reprinted in 2 BAYEFSKY, supra note 83, at 574-78. A revised property clause reemerged in the federal draft in the summer of 1980 ( $\$ 9$ of the Federal Government's Discussion Draft. July 4, 1980, 2 id. at 599, 601), but again facing strong opposition from the provinces (ROMANOW ET AL., supra note 106, at 77), the property clause was finally dropped in the Federal Government's Discussion Draft. Aug. 22, 1980, reprinted in 2 BAYEFSKY, supra note 83, at 669-73. The provinces feared that a Charter property right could impair provincial economic policies, such as restrictions on land ownership by nonresidents and the nationalization of certain resource industries, and they raised the more general concern that since the provinces held primary jurisdiction over the regulation of private property (CAN. CONST. (Constitution Act, 1867), $\$ 92(13)$ ), the entrenchment of property rights would have the greatest impact on the provinces (Alvaro, supra note 75, at 319). Although they had been omitted from the federal draft of the Charter, property rights became the object of intense dispute during the proceedings of the Hays-Joyal Committee in 1980 and 1981. Organizations appearing before the committee criticized the Charter for failing to protect property rights. See, e.g., 27 HAYS-JoYAL COMMITTEE MiNuTES OF Prockedings, supra note 92, at 40-41 (Alberta Chamber of Commerce); 33 id. at 134-35 
Since 1982, there have been several attempts to amend the Charter to protect property rights. ${ }^{107}$ Opponents of these various efforts from across the political spectrum invoked the ghost of Lochner. One Liberal Member of Parliament (MP) stated, "[o]ne also has to look at what happened in the United States... We know that the Bill of Rights was used for many years to prevent the stoppage of child labour. It was also used to prevent groups from unionizing. It was also deemed that the establishment of minimum wage laws could infringe upon the Bill of Rights." 108 A Progressive Conservative (PC) MP tied

(Business Council on National Issues); 15 id. at 9 (Canadian Bar Association). Although the federal government initially held steadfast to its refusal to protect property rights (e.g., Testimony of Jean Chrétien, in 4 HAYS-JoYAl COMMTTEE MINUTES OP PROCEEDINGS, supra note 92, at 86), a shift in the dynamic of the proceedings came when the acting minister of justice. Robert Kaplan. suddenly agreed to accept an amendment incorporating property rights in response to a question from a Progressive Conservative (PC) member of the Committee, 43 id. at 49. This unannounced shift in government policy was staged: Trudeau had come under pressure to include property rights from members of his cabinet and had agreed to do so if the proposal came from the opposition (ROBERT Sheppard \& Michart. Valpy, The National, Deal: The Fight for a Canadian Consttiution 143 (Fleet Books 1982)). However, the Liberal government came under immediate and intense pressure to withdraw its support for the amendment. The New Democratic Party (NDP) publicly announced that it would withdraw its support for the Charter if property rights received constitutional protection (NDP May Withdraw Support for PM's Plan. Toronro STAR. Jan. 26, 1981, at A1). As well. the NDP government of Saskatchewan, in private negotiations, demanded the omission of property rights in exchange for agreement on other issues, including proposed amendments on natural resources (Romanow ET AL., supra note 106, at 126). Minister of Justice Jean Chrétien accordingly withdrew the government's support for the amendment (45 HAYS-JOYAL COMMTTEE MiNUTES OF ProceEdings, supra note 92, at 9-10).

${ }^{107}$ While in opposition, backbench MPs of the PC party introduced a resolution in the House of Commons in 1983 to amend the Charter to add property rights. House OF CoMmons DeBATEs 24996 (April 29, 1983); motion defeated id. at 25052-53 (May 2, 1983). Once the PC party formed the government in 1984, backbench MPs introduced further resolutions in 1984, twice in 1985, and in 1987, none of which was put to a vote. House OF COMMONS DEBATES 979 (Dec. 6, 1984); HousE OF Commons Debates 1933 (Feb. 1, 1985); House of Commons DeBates 5163 (May 28, 1985). The 1987 resolution was adopted by the House of Commons in 1988 but the federal government never acted on it. House of COMmOns DeBates 10015 (Oct. 15, 1987). There has been activity at the provincial level as well. British Columbia, New Brunswick, and Ontario passed resolutions to amend the Charter to entrench property rights in 1982, 1983, and 1986. respectively. DEBATES OF THE Legislative Assembly of British Columbia 9309 (Sept. 21, 1982), Journals of thB Legislative Assembly of THE Province of New Brunswick 4195 (June 28, 1983); 71 Ontario Legislative Assembly Debates 3715-16 (Nov. 27, 1986). Finally, at the beginning of the so-called Canada Round of constitutional negotiations from 1991 to 1992, the federal government unsuccessfully proposed the amendment of the Charter to protect property rights. Canada. SHaPing Canada's Future Together: Proposals 3 (Supply and Services Canada 1991). This proposal never made its way into the final package of constitutional amendments-known as the Charlottetown Accordthat was voted on in a national referendum in 1992. CONSENSUS REPORT ON THE CONSTTUTION: Charlottetown, August 28, 1992: Final Text (1992).

${ }^{108}$ House of COMMONS DeBATES 981 (Dec. 6, 1984) (Don Boudria). The next year, he referred once again to Lochner with alarm: "[l]et us go back in history and look at what happened to the same issue in the United States. For a great many years, courts in the United States interpreted the 
Lochner to contemporary concerns, suggesting that "a substantive due process approach" to the interpretation of an amended section 7 could undermine the efficacy of matrimonial property regimes. ${ }^{109}$ Finally, as one would expect, an MP from the New Democratic Party (NDP) reminded the House of Commons that the Lochner era court had relied on the due process clauses in the Fifth and Fourteenth amendments "to strike down laws providing for minimum wages, maximum hours of work and maximum prices, and prohibiting anti-union activity." ${ }^{110}$ Similar concerns were raised in provincial legislatures. An NDP member of the Ontario legislature stated, "[T]here have been problems in the U.S. with property rights. For example, the right to regulate freight rates was challenged and the government was prevented from regulating freight rates. As well, the whole question of mortgages was raised in the U.S. and the courts prevented farmers from postponing mortgages because of property rights of the banks."111 Witnesses appearing before the Special Joint Committee on a Renewed Canada (the Beaudoin-Dobbie Committee), which was charged with the task of reviewing 1991 federal proposals to add property rights to the Charter, also made reference to the Lochner Court to illustrate the disadvantages of entrenching property rights. ${ }^{112}$ For example, representatives of women's groups invoked Lochner in testimony that largely focused on the danger posed by constitutional property rights to affirmative action programs, landlordtenant legislation, matrimonial property regimes, pay equity legislation, antidiscrimination statutes, and antipornography legislation. ${ }^{113}$ One member

inclusion of property rights as precluding legislators from enacting minimum wage laws. What would happen if that would be the effect here in Canada?" Id. at 1938 (Feb. 1, 1985) (Don Boudria).

${ }^{109}$ Id. at 986 (Dec. 6. 1984) (Mary Collins). Ms. Collins asked members of the House of Commons to "recall the case of Lochner versus New York ... in which the United States Supreme Court struck down a statute prescribing maximum weekly and daily hours of work for bakers on the grounds that it affected the deprivation of property rights without due process of law," and stated that "[t]he American courts also applied a substantive due process of law doctrine to invalidate statutes relating to minimum wages and child labour." Another PC MP referred with apparent concern "to the experience in the United States in the first few decades of this century. During that time, the courts invoked the due process clause of the U.S. Constitution to strike down social and economic legislation." Id. at 5170 (May 28, 1985) (Léo Duguay).

${ }^{110}$ Id. at 10020 (Oct. 15, 1987) (Lorne Nystrom). See also id. at 12504 (Feb. 1, 1988) (Ian Waddell).

11171 Ontario Legislative Assembly Debates 3711 (Nov. 27, 1986) (Floyd Laughren).

1127 Canada, Special Joint Committee on a Renewed Canada, Minutes of Proceedings and Evidence 70 (Jan. 21, 1992) (Lynda Haverstock) (testimony by leader of Liberal Party of Saskatchewan referring to the striking down of New Deal legislation that would have established farm-debt moratoriums).

${ }^{113} 43$ id. at 5 (Jan. 15, 1992) (Jeanne d'Arc Gaudet, testifying on behalf of the Advisory Council on the Status of Women of New Brunswick); 56 id. at 15-16 (Jan. 28. 1992) (Lynn Gaudet, testifying on behalf of the Yukon Status of Women Council). Lynn Gaudet also referred specifically to 
of the Beaudoin-Dobbie Committee described "the history of property rights in the United States" as one in which "these rights have always been for the benefit of the wealthy" and were "used to strike down good social legislation." 114 Thus, Lochner not only influenced the initial drafting of the Charter, but also was invoked to oppose amendments to entrench property rights. ${ }^{115}$

\subsubsection{Constitutional interpretation}

Section 7 contains two textual ambiguities that have driven much of the case law interpreting that provision. The first is the substitution of "fundamental justice" for "due process," raising the question of whether "fundamental justice" connotes procedural or substantive protection for the interests enumerated in the provision. The drafting history supports the procedural interpretation. The second ambiguity is the inclusion of "liberty," a term broad enough to extend beyond physical liberty to encompass both decisional autonomy or privacy and economic liberty. But once again. the drafting history, particularly the omission of property, suggests at least an intention to reject the economic interpretation of that term. As each of these ambiguities has come before the courts, the fear of Lochnerizing the Charter-in its various senseshas been a paramount consideration for litigants, the Supreme Court of Canada, and the Court's critics.

The question of whether the principles of fundamental justice encompass substantive as well as procedural protection came before the Supreme Court just three years after the Charter came into force, in the Reference Re Motor Vehicle Act case. ${ }^{116}$ The case generated a considerable amount of controversy, because the lower court had held that, notwithstanding the drafting history of section 7, "fundamental justice" imposed substantive limitations on legislative

minimum wage laws, a type of law struck down by the Lochner court. See 26 id. at 66-67 (Dec. 9. 1991) (Gord Thompson, testifying on behalf of the Canadian Home Builders' Association).

11421 id. at 23 (Dec. 2, 1991) (Ian Waddell).

${ }^{115}$ Lochner also frames the structure of the post-1982 academic literature on whether a property rights amendment would spawn libertarian jurisprudence. Joel Bakan, for example, argued that the 1991 federal proposal to entrench property rights was dangerous because the rise of neoliberalism would shape the interpretation of that provision, in the same way that the ideology of laissezfaire had shaped the constitutional interpretation of the Fifth and Fourteenth amendments by the Lochner Court. Joel Bakan, Against Constitutional Property Rights, in Constitutional PoLTTCs: The Canadian Forum Book on the Federal Constitutional Proposals, 1991-92, 117, 123-25 (Duncan Cameron \& Miriam Smith eds., James Lorimer \& Co. 1992). Positive or ambiguous assessments of these amendments have suggested, conversely, that the risk of Lochner is somewhat remote. Writing in response to the 1983 resolution introduced in the House of Commons, and before the emergence of neoliberalism in Canada. Claire Beckton suggested that a libertarian interpretation of a property clause was "highly unlikely" because the philosophy of laissez-faire was anachronistic. Clare E. Beckton. The Impact on Women of Entrenchment of Property Rights in the Canadian Charter of Rights and Freedoms, 9 DALHOUSIE L.J. 288, 311 (1985).

${ }^{116}$ Reference Re Section 94(2) of the Motor Vehicle Act (B.C.). [1985] 2 S.C.R. 486 (Can.). 
competence, and, in particular, prohibited the enactment of absolute liability offenses. Moreover, the lower court did no more than invoke "the public interest" as the basis for determining when a deprivation of a protected interest would be "fundamentally unjust." The critique of Lochner as activist-i.e., where a court substitutes its own views on public policy for those of the legislature-provided a rhetorically powerful tool to challenge this holding.

The link with Lochner was made most explicitly in Reference Re Motor Vehicle Act by the attorney general of Ontario (AGO), who had intervened in the case before the Supreme Court. The AGO articulated this connection in two different ways. First, the AGO made much of the deliberate choice of the framers of the Charter to not rely on "due process" in the drafting of section 7, describing the taint that now attached to that term in the context of substantive due process. The AGO then drew a direct analogy between the Lochner era and the judgment of the lower court, stating that it opened the door to the constitutionalization of judicial policy preferences:

At its high water mark, the "American" concept [of due process] served to render inoperative state-enacted legislative schemes aimed at regulating matters within the legislative competence of the states. These provisions were struck down because they offended certain basic economic policies which the Court regarded as ingrained in the United States Constitution through the due process clause. Those contending for a negative answer in this case, seek to give the same scope to the "fundamental justice" requirement. If one substitutes criminal law policies for economic policies, one can see that the British Columbia Court of Appeal [i.e., the lower court] in this case engaged in a type of review which is identical to that employed under the "due process" clause by the United States Supreme Court in the late nineteenth and early twentieth centuries. ${ }^{117}$

The critical reading of Lochner's activism is reinforced by the next paragraph, which shifts attention to the modern privacy jurisprudence to illustrate "that American courts continue to employ the 'due process' clause to review the suitability of social policies." ${ }^{118}$ The message in these passages is that against the background of this controversy, the choice by the Canadian framers of wording other than "due process" suggests a clear intent not to follow the lead of the American courts. ${ }^{119}$

This theme in the AGO's submissions is supplemented by a second onethat even had "due process" been employed, substantive due process is so

${ }^{117}$ Factum of the Attorney General of Ontario, $\uparrow 36$.

${ }^{118}$ Id. ๆ 37. For the same point, see Factum of the Appellant Attorney General of British Columbia. 1 57; Factum of the Attorney General of Alberta. I 4.

${ }^{119}$ Factum of the Attorney General of Ontario. 139 . For the same point, see Factum of the Appellant Attorney General of Brttish Columbia. ๆ 57; Factum of the Attorney General of Alberta, \4. 
fraught with institutional danger that it ought to be avoided. To make this point, the AGO relied on the pre-Charter case law under the Canadian Bill of Rights, which protects "the right of the individual to life, liberty, security of the person and enjoyment of property, and the right not to be deprived thereof except by due process of law." ${ }^{120}$ In a case cited by the AGO. Justice (later Chief Justice) Bora Laskin had suggested that "due process" could be given a substantive interpretation, but, discussing the Lochner era, had drawn the lesson "that a Court enters the bog of legislative policy-making in assuming to enshrine any particular theory, as for example, untrammelled liberty of contract, which has not been plainly expressed in the Constitution." ${ }^{121}$ For Justice Laskin, the lesson of Lochner was:

extreme caution... when asked to apply them [the words "due process"] in negation of substantive legislation validly enacted by a Parliament in which the major role is played by elected representatives of the people.... [Adjudication] must be grounded on more than a substitution of a personal judgment for that of Parliament. ${ }^{122}$

Invoking Justice Laskin's analysis, the AGO in Reference Re Motor Vehicle Act asserted that the "public interest" standard applied by the lower court would invite the courts "to Lochner" under the rubric of fundamental justice- that is, to conduct an "open ended and entirely subjective review of substantive law provisions," 123 and "to make the judiciary a super-legislature sitting in review of the policy objectives selected by the legislature." 124 To reinforce the institutional dangers of judicial activism, the AGO discussed the "crisis in the 1930's that abated only when the court all but abandoned its attempts to promote its view of the appropriate economic policies." 125

Justice Lamer's majority judgment, which adopted a substantive interpretation of "fundamental justice," responded directly to these submissions. His first move was to minimize the relevance of the American experience of substantive due process to the interpretation of the Charter, suggesting that "[w]e would... do our own Constitution a disservice to simply allow the American

${ }^{120}$ Canadian Bill of Rights, ch. 44, 1960 S.C. $519 . \$ 1$ (a) (Can.), reprinted in R.S.C. app. III (1985), Tा 43-45 (Can.). This case was discussed in the Factum of the Attorney General of Ontario, जा $43-45$.

${ }^{121}$ R. v. Curr, [1972] S.C.R. 889.902 (Can.).

${ }^{122}$ Id.

${ }^{123}$ Factum of the Attorney General of Ontario, $\$ 46$.

${ }^{124}$ Id. ๆ 48. See also Supplementary Factum of the Appellant Attorney General of British Columbia. I 14 ("the opinion of the elected representatives of the people as to the fairness of legislation must hold sway over the opinion of an appointed court" (underline in original)) and Factum of the Attorney General of Saskatchewan, $\mathbb{1} 17$ ("a substantive interpretation of section 7 would effectively transform the courts from constitutional adjudicators to legislative policy makers").

${ }^{125}$ Factum of the Attorney General of Ontario, 949. 
debate to define the issue for us, all the while ignoring the truly fundamental structural differences between the two constitutions."126

Justice Lamer's opposition to examining the American experience was fundamentally at odds with the drafting history of section 7 , which made the relevance of substantive due process unavoidable. It is, therefore, not surprising that Justice Lamer went on to accept the force of the critique of Lochner, and to attempt to deflect it. Thus, he agreed with the submission that the interpretation of "the principles of fundamental justice" should not lead to the "adjudication of the merits of public policy"127 or of the "wisdom" of legislation, ${ }^{128}$ an argument clearly framed with the Lochner era in mind. His compromise was to define the principles of fundamental justice narrowly, as "the basic tenets of our legal system," which are both procedural and substantive in nature. ${ }^{129}$ Justice Lamer took this principle to encompass, inter alia, the principles of the criminal justice system. He noted that this was an area in which the Court had specific expertise, and which, as a consequence, lay "in the inherent domain of the judiciary." 130

Both the limited scope of the Court's interpretation of the principles of fundamental justice and the appeal to judicial competence were clearly designed to deflect the criticism that, in adopting a substantive interpretation of "the principles of fundamental justice," Justice Lamer had done little more than open the door to the Court's substitution of its own views on public policy for those of the legislature. Critics of the judgment, however, argued that this is exactly what Justice Lamer had done and cited Lochner as the paradigmatic example of this sort of judicial activism. Jamie Cameron, for example, engaged in a lengthy discussion of Lochner-era substantive due process. She adopted an activist reading of Lochner, and drew a direct link with Justice Lamer's judgment, stating "like Lamer, J., in this era the U.S. Supreme Court typically pleaded innocent disregard of the merits of legislation under review," whereas "[i]t became patently clear, in the line of cases following Lochner v. New York,

\footnotetext{
${ }^{126}$ Reference Re Section 94(2) of the Motor Vehicle Act (B.C.), [1985] 2 S.C.R. 486, 498 (Can.). Justice Lamer suggested that the distinction between a substantive and a procedural interpretation of $\S 7$ was "largely bound up in the American experience with substantive and procedural due process" and "import[ed] into the Canadian context American concepts, terminology and jurisprudence, all of which are inextricably linked to problems concerning the nature and legitimacy of adjudication under the U.S. Constitution." Id.

${ }^{127}$ Id. at 499.

${ }^{128} I d$.

${ }^{129} \mathrm{Id}$. at 503.

${ }^{130}$ Id. On the facts of the case, the relevant principle was that "the innocent shall not be punished," which was contravened by offenses of absolute liability punishable by imprisonment, because persons convicted of such offenses could suffer a loss of physical liberty without possessing a guilty mind.
} 
that the court held statutes unconstitutional only because a majority disagreed with the policy objectives of the legislature." ${ }^{131}$ She went on to argue:

[T]his history should ... have held interest for Lamer, J.... [I]t illustrates why the legitimacy issue arises when a court injects non-textual, substantive values into a clause addressing procedural issues, and then places those values beyond legislative intervention. The content of due process is not subject to control, and once certain values receive constitutional protection an unremovable and unaccountable judiciary has defied the will of a removable and accountable representative body.... Had Lamer, J. reviewed the painful history of the Lochner era, he might have been inclined to reach his decision on other grounds... ${ }^{132}$

Perhaps it is precisely because of Lochner that Justice Lamer framed "the principles of fundamental justice" in light of the criminal justice system to serve as a legitimizing device designed to disinherit the judicial activism strand of Lochner's legacy.

The second line of cases on section 7 deals with the scope of the "liberty" interest protected by that provision. Whether and to what extent economic freedom is encompassed by the liberty interest has generated a surprising amount of litigation, both in the Supreme Court and the lower courts. The first two decisions from the Supreme Court on this issue quickly sent the message that freedom of contract falls outside the scope of section 7. The first of these, $R$. $v$. Edwards Books, was a constitutional challenge to Sunday closing legislation. ${ }^{133}$ Although the case was resolved on the basis of the Charter's guarantee of freedom of religion, ${ }^{134}$ one of the parties challenging the legislation also invoked section 7, arguing that the liberty interest encompassed "economic freedom" and citing two Lochner-era judgments on the Fourteenth Amendment. ${ }^{135}$ Moreover, the claimant characterized the Sunday closing law as illegitimate class legislation, in language that could have come from the Lochner Court. ${ }^{136}$

\footnotetext{
131 Jamie Cameron. The Motor Vehicle Reference and the Relevance of American Doctrine in Charter Litigation, in CHARTER LITIGATION 69, 84 (Robert J. Sharpe ed., Butterworths 1987).

$132 \mathrm{Id}$. at 86. See also Hawkins, supra note 75, at 291, where he accused Justice Lamer of "Lochnerizing."

${ }^{133}$ R. v. Edwards Books and Art Ltd., [1986] 2 S.C.R. 713 (Can.).

${ }^{134}$ Section 2(a) provides that "Everyone has the following fundamental freedoms... freedom of conscience and religion..." Charter, supra note 10. $\$ 2(a)$. The Court found that the legislation contravened $\S 2(a)$, but found that the violation was justified under $\S 1$.

${ }^{135}$ The claimant, Paul Magder, cited (a) State v. Dodge, 76 Vt. 197 (1904) at $\llbracket 21$ of his factum, and (b) Pavesich v. New England Life Insurance Co., 50 S.E. 68 (1905) at I 64 of his factum. Factum of the Appellant Paul Magder.

${ }^{136}$ Magder argued that "fundamental justice" was equivalent to "due process," and that the latter permitted governments to limit economic freedom only if they adhere to the principle that
} 
The Supreme Court summarily dismissed this argument, but without any reference to the American Constitution. ${ }^{137}$ Yet three years later, the Court felt itself compelled to compare the texts of the Charter and the American Constitution, in rejecting a similarly framed constitutional challenge to a prohibition on advertising directed at children, inter alia, on the basis of economic liberty. ${ }^{138}$ The Court rejected this claim on the basis of a comparison of the wording of section 7 and the Fifth and Fourteenth amendments. ${ }^{139}$ It reasoned that two differences between the provisions-the absence of protection for property in the Charter, and the substitution of security of the person for property in the Charter-colored the interpretation of the liberty interest and led "to a general inference that economic rights as generally encompassed by the term 'property' are not within the perimeters of the s. 7 guarantee." 140 The Court interpreted section 7 in exactly the manner envisioned by the framers of the Charter.

These clear, albeit infrequent, signals from the Supreme Court rejecting a constitutionalized economic libertarianism stand in stark contrast to the tumultuous lower court jurisprudence of the same period. Notwithstanding

"[g]overnments are to operate for the common benefit of the people, and not for the particular advantage of any special interest group." Factum of the Appellant Paul Magder. $\uparrow \mathbb{6} 66$ and 20. He urged that the legislation did not meet this standard, because it was "anti-competitive and protectionist." as revealed by the exemptions it created for businesses operating in tourist areas, and hence was "designed to serve particular special interests." Id. I 21 and 22. The Attorney General of Ontario responded by noting the deliberate omission of property from section 7, and he inferred from that decision the exclusion of any protection for "economic freedoms" through the interests enumerated therein. Factum of the Respondent Attorney General of Ontario, ๆ 95. Distinguishing the American case law on the basis of differences in the constitutional texts, he drew a comparison between section 7 and the Fifth and Fourteenth amendments, suggesting that inclusion of property colored the American provisions as a whole and accounted for the interpretation of liberty as encompassing freedom of contract. These submissions were adopted by the attorneys general of Manitoba, Newfoundland, Quebec, and Saskatchewan, who intervened in the appeal. Factum of the Attorney General of Manitoba. If 3; Factum of the Attorney General of Newfoundland. ๆ 5; Factum of Attorney General of Quebec, 123 ; Factum of the Attorney General of Saskatchewan, 13.

${ }^{137}$ R. v. Edwards Books and Art Ltd., [1986] 2 S.C.R. 713, 785-86 (Can.).

${ }^{138}$ Irwin Toy v. Quebec (Attorney General), [1989] 1 S.C.R. 927 (Can.). The challenge and the judgment focused on $\S 2(\mathrm{~b})$, which provides that "[e]veryone has the following fundamental freedoms... freedom of thought, belief, opinion and expression, including freedom of the press and other media of communication..." Charter, supra note $10, \S 2$ (b). The Court found that the law violated $\S 2$ (b), but was saved under $\S 1$.

${ }^{139}$ Id. at $1003-4$.

${ }^{140} \mathrm{Id}$. at 1003 . The Court also held that omission of economic interests from $\S 7$ meant that corporations were excluded from the class of entities that could hold rights under the provision, notwithstanding that $\S 7$ rights are guaranteed to "everyone." Id. at 1004. This holding was confirmed in Dywidag Systems International. Canada Ltd. v. Zutphen Brothers Construction Ltd. [1990] 1 S.C.R. 705, 709 (Can.). 
the drafting history of section 7, and the reflection of that history in the text of the provision, claimants pleaded section 7 in constitutional challenges to a vast array of legislation restricting economic liberty until 1989. The impugned laws were diverse, tracking the variety and scope of Lochner-era challenges to economic regulation. Some cases concerned challenges to commercial regulations that governed, for example, the operation of hotels ${ }^{141}$ and arcades, ${ }^{142}$ dairy farming, ${ }^{143}$ the sale of alcohol, ${ }^{144}$ the sale of pharmaceuticals, $^{145}$ Sunday closings, ${ }^{146}$ advertising, ${ }^{147}$ and the manufacture of goods. ${ }^{148}$ There were challenges to laws that resembled regulatory takings, such as those requiring the compulsory licensing of patents for medicines, ${ }^{149}$ establishing rent controls, ${ }^{150}$ and setting limits on the right to contract in bankruptcy legislation. ${ }^{151}$ Other cases challenged limitations on rights to real property, such as restrictions on a landlord in recovering possession of premises, ${ }^{152}$ expropriations, ${ }^{153}$ restrictions on the locations of group homes, ${ }^{154}$ and restrictions on land ownership by nonresidents of a province. ${ }^{155}$ Section 7 was

\footnotetext{
${ }^{141}$ Re D \& H Holdings and City of Vancouver, 21 D.L.R. (4th) 230 (B.C. Sup. Ct. 1985).

${ }^{142}$ Francen v. City of Winnipeg, 40 Man. R. (2d) 137 (Ct. App. 1986).

${ }^{143}$ Milk Board v. Clearview Dairy Farm Inc., 69 B.C.L.R. 220 (Sup. Ct. 1986), aff'd. 12 B.C.L.R. (2d) 116 (Ct. App. 1987).
}
${ }^{144}$ Parkdale Hotel Ltd. v. Canada (Attorney General), 2 F.C. 514 (Fed. Ct. Trial Div. 1986); Re Homemade Winecrafts (Canada) Ltd. v. British Columbia (Attorney General), 26 D.L.R. (4th) 468 (B.C. Sup. Ct. 1986); R. V. P. Enterprises Ltd. v. British Columbia (Minister of Consumer and Corporate Affairs), 12 B.C.L.R. (2d) 244 (Sup. Ct. 1987), aff'd, 25 B.C.L.R. (2d) 219 (Ct. App. 1988).
${ }^{145}$ Bassett v. College of Physicians and Surgeons of Saskatchewan, 63 Sask. R. 45 (Q.B. 1987).
${ }^{146}$ Peel (Regional Municipality) v. Great Atlantic \& Pacific Co. of Canada Ltd., 73 O.R. (2d) 289 (High Ct. J. 1990).

${ }^{147}$ R. v. Pinehouse Plaza Pharmacy Ltd., 67 Sask. R. 201 (Q.B. 1988).

${ }^{148} \operatorname{Re}$ Aluminum Co. of Canada, Ltd. and Ontario (Minister of the Environment), 55 O.R. (2d) 522 (Div. Ct. 1986).

${ }^{149}$ Smith, Kline \& French Laboratories Ltd. v. Canada (Attorney General), 1 F.C. 274 (Fed. Ct. Trial Div. 1986), aff'd. 2 E.C. 359 (Ct. App. 1987).

${ }^{150}$ Haddock v. Ontario (Attorney General), 73 O.R. (2d) 545 (High Ct. J. 1990).

${ }^{151}$ Skalbania (Trustee of) v. Wedgewood Village Estates Ltd., 37 B.C.L.R. (2d) 88 (Ct. App. 1989).

152 Turbo Resources Ltd. v. Rotchell, 38 Sask. R. 205 (Q.B. 1985).

${ }^{153}$ Becker v. Alberta, 45 A.R. 37 (Q.B. 1983): Manicom v. County of Oxford, 52 O.R. (2d) 137 (High Ct. J. 1985).

${ }^{154}$ Alcoholism Foundation of Manitoba v. City of Winnipeg, 59 Man. R. (2d) 83 (Q.B. 1988), rev'd, 65 Man. R. (2d) 81 (Ct. App. 1990).

${ }^{155}$ Reference Re Lands Protection Act (P.E.I.), 64 Nild. \& P.E.I.R. 249 (Ct. App. 1987). 
also used to challenge features of the federal income tax ${ }^{156}$ and the excise tax. ${ }^{157}$ Challenges to the constitutionality of restrictions on the right to pursue claims in tort and contract, for example, by eliminating causes of action ${ }^{158}$ or limiting liability, ${ }^{159}$ generated section 7 challenges as well. For the most part, litigants framed the above challenges in terms of the deprivation of their "liberty," understood to contain an economic component. And again for the most part, these challenges were spectacular failures, with courts almost uniformly holding that section 7 does not protect economic rights. ${ }^{160}$ But in two other

${ }^{156}$ Fleming v. Minister of National Revenue, 2 C.T.C. 2192 (Can. Tax Ct. 1986): Androwich v. Canada, 1 C.T.C. 78 (Fed. Ct. Trial Div. 1990).

${ }^{157}$ Vanguard Coatings and Chemicals Ltd. v. Canada (Minister of National Revenue), 1 E.C. 367 (Fed. Ct. Trial Div. 1987).

${ }^{158}$ See, e.g., Budge v. Alberta (Workers' Compensation Board), 80 A.R. 207 (Q.B. 1987), rev'd, 111 A.R. 228 (Ct. App. 1991): Re Energy Probe and Canada (Attorney General), 61 O.R. (2d) 65 (High Ct. J. 1987); Roncato v. O’Brien, No. 1403/87, Quicklaw [1987] O.J. No. 1285 (Dist. Ct. Oct. 16, 1987).

${ }^{159}$ Whitbread v. Walley, 26 B.C.L.R. (2d) 203 (Ct. App. 1988).

${ }^{160}$ See, e.g., Becker v. Alberta, 45 A.R. 37 (Q.B. 1983); Turbo Resources Ltd. v. Rotchell, 38 Sask. R. 205 (Q.B. 1985); Manicom v. County of Oxford, 52 O.R. (2d) 137 (Div. Ct. 1985); Smith. Kline \& French Laboratories Ltd. v. Canada. 2 E.C. 359 (Ct. App. 1986); R. v. Professional Technology of Canada Ltd., 12 C.P.R. (3d) 218 (Alta. Prov. Ct. 1986); Re Homemade Winecrafts (Canada) Ltd. and British Columbia (Attorney General), 26 D.L.R. (4th) 468 (B.C. S.C. 1986); Re Malartic Hygrade Gold Mines (Canada) Ltd. and Ontario Securities Commission, 54 O.R. (2d) 544 (Div. Ct. 1986): Grant v. Crane Construction Corp.. 3 B.C.L.R. (2d) 114 (Sup. Ct. 1986); Re Aluminum Co. of Canada Ltd. and Ontario, 55 O.R. (2d) 522 (Div. Ct. 1986); Dywidag Systems International Canada Ltd. v. Zutphen Brothers Construction Ltd., 75 N.S.R. (2d) 187 (Sup. Ct. 1986), aff'd. 76 N.S.R. (2d) 398 (Ct. App. 1987), aff'd on different grounds. [1990] 1 S.C.R. 705 (Can.); Fleming v. Minister of National Revenue, 2 C.T.C. 2192 (Can. Tax. Ct. 1986); R. v. Chomski, Quicklaw [1986] O.J. No. 1596 (Ont. Prov. Ct. Aug. 12, 1986); Re Yorkville North Development Ltd. and City of North York, 57 O.R. (2d) 172 (Dist. Ct. 1986); Vanguard Coatings and Chemicals v. Minister of National Revenue, 1 F.C. 367 (Fed. Ct. Trial Div. 1986), aff'd, 3 E.C. 560 (Ct. App. 1988); Byrt v. Saskatchewan, 56 Sask. R. 111 (Q.B. 1986); Bassett v. Canada, 53 Sask. R. 81 (Sask. Ct. App. 1987); Omni Health Care Ltd. v. Canadian Union of Public Employees. No. 391/86, Quicklaw [1987] O.J. No. 2255 (High Ct. J. Jan. 29, 1987); Re G. E. Z.. Quicklaw [1987] M.J. No. 643 (Prov. Ct. Feb. 17. 1987); R. V. P. Enterprises Ltd. v. British Columbia (Minister of Consumer and Corporate Affairs), 12 B.C.L.R. (2d) 244 (Sup. Ct. 1987), aff'd, 25 B.C.L.R. (2d) 219 (Ct. App. 1988); Kuntz v. College of Physicians and Surgeons of British Columbia, No. A870116. Quicklaw [1987] B.C.J. No. 724 (B.C. Sup. Ct. Mar. 6. 1987); Charalambous v. College of Physicians and Surgeons of British Columbia. No. A863111, Quicklaw [1987] B.C.J. No. 1212 (Sup. Ct. Apr. 24. 1987); Benoit v. Gestion Tex-Di Inc., R.J.Q. 1401 (Sup. Ct. 1987); Reference Re Lands Protection Act (P.E.I.), 64 NHA. \& P.E.I.R. 249 (P.E.I. Sup. Ct. 1987); R. v. Myrrmidon Inc., 48 Man. R. (2d) 105 (Q.B. 1987), aff'd, 52 Man. R. (2d) 303 (Ct. App. 1988); Hillcrest Contractors Ltd. v. McIntyre. 62 Sask. R. 251 (Q.B. 1987): Home Orderly Services Ltd. v. Manitoba, 45 Man. R. (2d) 200 (Q.B. 1987), aff'd, 49 Man. R. (2d) 246 (Ct. App. 1987); Apsassin v. Canada (Department of Indian Affairs and Northern Development). [1988] 3 F.C. 20 (Trial Div.): Whitbread v. Walley. 19 B.C.L.R. (2d) 120 (Sup. Ct. 1987). § 7, analysis aff'd. 26 B.C.L.R. (2d) 203 (Ct. App. 1988); Institute of Edible Oil Foods v. Ontario, 63 O.R. (2d) 436 (High Ct. J. 1987); O.P.S.E.U. v. Northern College of Applied Arts and Technology, 28 O.A.C. 100 (Div. Ct. 1988); Weyer v. Canada. 83 N.R. 272 
sets of cases, claimants enjoyed much greater success. The first of these cases centered on challenges to the regulation of the professions and raised the question of whether the right to engage in a profession fell within the scope of the "liberty" interest. ${ }^{161}$ The second set of cases arose out of the suspension of motor vehicle licenses and raised for judicial determination whether "liberty" encompassed the right to drive. ${ }^{162}$

Anti-Lochnerism loomed large in this mass of case law. In challenges that were unsuccessful, courts used textual arguments-comparing section 7 with

(Fed. Ct. App. 1988); Phillips v. Moose Jaw Police Commissioners, 67 Sask. R. 49 (Q.B. 1988); R. v. Pinehouse Plaza Pharmacy Ltd., 67 Sask. R. 201 (Q.B. 1988), aff'd. 89 Sask. R. 47 (Q.A. 1991); Metropolitan Stores (MTS) Ltd. v. Manitoba Food and Commercial Workers, No. 8501-05620, Quicklaw [1988] M.J. No. 337 (Q.B. June 22, 1988); Bernard v. Dartmouth Housing Authority, 88 N.S.R. (2d) 190 (Sup. Ct. 1988): Anthony v. Misericordia General Hospital (Executive Director), No. 88-01-269260. Quicklaw [1987] M.J. No. 354 (Q.B. July 20, 1988); Skalbania (Trustee of) v. Wedgewood Village Estates Ltd., 31 B.C.L.R. (2d) 184 (Sup. Ct. 1988), aff'd, 37 B.C.L.R. (2d) 88 (Ct. App. 1989): Arlington Crane Service v. Ontario (Minister of Labour), 67 O.R. (2d) 225 (High Ct. J. 1988). The point that section 7 does not protect economic rights has been made in later judgments. See, e.g., Arlington Crane Service, 67 O.R. (2d) 225; Institute of Edible Oil Foods. 63 O.R. (2d) 436; Whitbread, 19 B.C.L.R. (2d) 120.

161 The best-known cases of this type were largely brought by physicians, who challenged geographic restrictions on the right to practice under provincial health insurance plans (Mia v. British Columbia (Medical Services Commission), 61 B.C.L.R. 273 (Sup. Ct. 1985) and Re Wilson and Medical Services Commission. 30 B.C.L.R. (2d) 1 (Ct. App. 1988)); the termination of admitting privileges by public hospitals (Stoffman v. Vancouver General Hospital, 30 D.L.R. (4th) 700 (B.C. Sup. Ct. 1986)); and discipline procedures employed by medical licensing authorities. With respect to the last category of cases: (a) for cases where courts found no deprivation of a protected interest, see Kuntz v. College of Physicians and Surgeons of British Columbia, No. A870116. Quicklaw [1987] B.C.J. No. 724 (Sup. Ct. Mar. 6, 1987); Charalambous v. College of Physicians and Surgeons of British Columbia, No. A863111, Quicklaw [1987] B.C.J. No. 1212 (S.C. Apr. 24, 1987); KhaliqKareemi v. Health Services and Insurance Commission (N.S.), 84 N.S.R. (2d) 425 (Sup. Ct. 1988), varied. 89 N.S.R. (2d) 388 (Ct. App. 1989): (b) for a case where courts found a deprivation to be in accordance with the principles of fundamental justice, see Yong $v$. College of Physicians and Surgeons of British Columbia. No. A852805, Quicklaw [1986] B.C.J. No. 2138 (Sup. Ct. Feb. 14. 1986); and (c) for a case where courts found a deprivation not in accordance with principles of fundamental justice, see Branigan v. Yukon Medical Council, 1 B.C.L.R. (2d) 350 (Yukon Sup. Ct. 1986).

${ }^{162}$ For examples of cases where courts found no deprivation of a protected interest, see R. v. Neale. 71 A.R. 337 (Ct. App. 1986); Re G. E. Z., Quicklaw [1987] M.J. No. 643: Paganelli v. Ontario (Registrar of Motor Vehicles), No. 1105/86. Quicklaw [1987] O.J. No. 2424 (Div. Ct. Mar. 31. 1987); Ginther v. Saskatchewan Government Insurance, 66 Sask. R. 109 (Ct. App. 1988). For cases where courts found a deprivation of a protected interest to be in accordance with principles of fundamental justice, see Hundal v. British Columbia (Superintendent of Motor Vehicles), 64 B.C.L.R. 273 (Ct. App. 1985); Re Zukowski and British Columbia, 25 D.L.R. (4 $\left.{ }^{\text {th }}\right) 627$ (B.C. Sup. Ct. 1986): Re Allen and Superintendent of Motor Vehicles, 27 C.C.C. (3d) 32 (B.C. Sup. Ct. 1986); R. v. Heidel, 48 Sask. R. 173 (Q.B. 1986); R. v. Miller, 55 O.R. (2d) 417 (High Ct. J. 1986). For cases where courts found a deprivation of a protected interest not to be in accordance with principles of fundamental justice, see R. v. Robson, 56 B.C.L.R. 194 (Sup. Ct. 1984), aff'd, 28 B.C.L.R. (2d) 8 (Ct. App. 1985); R v. Grant, 28 C.C.C. (3d) 32 (B.C. Sup. Ct. 1986); R. v. Nelson. 24 B.C.L.R. (2d) 221 (County Ct. 1988); R. v. Sengara, 26 B.C.L.R. (2d) 71 (Sup. Ct. 1988). 
the Fifth and Fourteenth amendments-later employed by the Supreme Court in Irwin Toy. ${ }^{163}$ Some courts went further, and specifically rejected Lochner's political economy theory. In Smith, Kline \& French Laboratories, Barry Strayer, now a justice of the Federal Court of Canada, dismissed the claimant's reliance on Lochner-era precedent, noting that

[r]eference to the jurisprudence of 1923 of the United States Supreme Court on the subject of "liberty" must also be viewed with caution. The concept of "liberty of contract," originally founded on the Fourteenth Amendment, scarcely survived the Great Depression in the United States ... [moreover] it must be kept in mind that the historical background and social and economic context of the Fourteenth Amendment are distinctly American. ${ }^{164}$

Lochner-era case law was disapproved of in another case, in which the court noted that "[ $t]$ he authority of Lochner has long... been almost entirely whittled away in the land of its birth.... I do not accept it as having any application to the meaning of 'liberty' in $\mathrm{s.} 7$ of the Charter." ${ }^{165}$ In a similar vein, another judgment noted that "[t]he different and expanded meaning accorded the word 'liberty' appears to find its source in American tradition, drawing heavily on so-called natural law or libertarian principles, philosophic principles espoused in that country in the late nineteenth century." 166

Successful litigants, conversely, were forced to navigate around Lochner. The dominant strategy employed in these cases was one of redescription-that is, the redescription of claims of economic liberty in terms that did not raise the specter of laissez-faire. This strategy was the most congenial to cases that lay on the border between different conceptions of liberty. Cases on the right to drive, for example, were brought by claimants motivated by economic considerations, because the suspension of a license diminished their capacity to earn a livelihood. To avoid the accusation of endorsing Lochner, the claimants characterized the "liberty" at stake as the physical liberty to move freely. ${ }^{167}$

\footnotetext{
${ }^{163}$ Becker v. Alberta, 45 A.R. 37 (Q.B. 1983): Gershman Produce Co. v. Manitoba (Motor Transport Board), 32 Man. R. (2d) 308 (Q.B. 1984), varied. 36 Man. R. (2d) 81 (Ct. App. 1985): Re Malartic Hygrade Gold Mines (Canada) Ltd. and Ontario Securities Commission, 54 O.R. (2d) 544 (Div. Ct. 1986); Re Homemade Winecrafts (Canada) Ltd. v. British Columbia (Attorney General). 26 D.L.R. (4th) 468 (B.C. Sup. Ct. 1986); Grant v. Crane Construction Corp., 3 B.C.L.R. (2d) 114 (Sup. Ct. 1986); Chomski, Quicklaw [1986] O.J. No. 1596; Re Yorkville North Development Ltd. and City of North York, 57 O.R. (2d) 172 (Dist. Ct. 1986).

${ }^{164}$ Smith, Kline \& French Laboratories Ltd. v. Canada (Attorney General), 1 F.C. 274, 314 (Trial Div. 1986).

${ }^{165}$ Skalbania (Trustee of) v. Wedgewood Village Estates Ltd., 37 B.C.L.R. (2d) 88, 97 (Ct. App. 1989).

${ }^{166}$ R. v. Neale, 71 A.R. 337. 341 (Ct. App. 1986).

${ }^{167}$ See, e.g., Gershman Produce Co., 32 Man. R. (2d) 308 (Q.B. 1984). But compare R. v. Robson, 56

B.C.L.R. 194, 199 (Sup. Ct. 1984) (stating that the liberty interest protects the right to earn a
} 
Cases limiting the right to practice a profession, by contrast, sought to break down the boundary between the economic liberty aspect and privacy/decisional autonomy aspect of substantive due process, given the plausible connection between choice of occupation and the pursuit of an individual's conception of the good. ${ }^{168}$

This latter set of cases sparked a debate in the academic literature. Critics attacked this attempt at redescription by recategorizing these cases under the heading of laissez-faire. David Lepofsky, for example, wrote of Wilson v. British Columbia (Medical Services Commission) ${ }^{169}$ — a case in which a court had found unconstitutional the geographic restrictions on the right of physicians to practice under a provincial health insurance plan-"[o]f the entire United States constitutional experience. Canadians can learn no better lesson than from the substantive due process era-a massive judicial mistake which we should avoid replicating." ${ }^{170}$ Academic defenders of the judgment responded, in turn. by claiming that it did not mark a return to Lochner's commitment to the free market. Hart Schwartz thus argued that "the court went out of its way to declare that it was not promoting a laissez-faire, or any other, economic approach" and that "[a] person who has trained, studied, and developed the skills and expertise to practise a profession or trade... clearly has her dignity and sense of self-worth impaired when informed by a government agency that she may no longer employ her skills."171

The indirect attempt to protect economic rights through section 7 in the lower courts provoked an outburst from Justice Lamer in 1990, with regard to a challenge to the criminal regulation of prostitution on the grounds that the law infringed the liberty of prostitutes to contract for their services. ${ }^{172}$

livelihood), aff'd, 28 B.C.L.R. (2d) 8, 11 (Ct. App. 1985) (stating that the liberty interest encompasses the "liberty to employ one's skill and ability").

${ }^{168}$ In Mia v. British Columbia (Medical Services Commission), 61 B.C.L.R. 273, 304 (Sup. Ct. 1985), the court cited Meyer v. Nebraska, 262 U.S. 390 (1923) in support of this move. Meyer was a Lochner-era case on noneconomic substantive due process that survived the 1930 s and held that liberty encompassed the right "to engage in any of the common occupations of life." Id. at 399.

16930 B.C.L.R. (2d) 1 (Ct. App. 1988).

${ }^{170}$ M. David Lepofsky, A Problematic Judicial Foray into Legislative Policy-Making: Wilson v. B.C. Medical Services Commission, 68 CAN. B. Rev. 61 5, 626 (1989). Leopofsky suggested that interpreting the liberty interest to encompass the right to practice a profession, coupled with a substantive interpretation of the principles of fundamental justice, would create "a Canadian equivalent to United States style substantive due process. replete with all of its dangers," and that the "court assumed the legislature's mantle as had United States courts for three decades... implicitly impressing on the public one particular economic philosophy." Id.

${ }^{171}$ Hart Schwartz, In Defence of Wilson: Wilson v. Medical Services Commission of British Columbia, 69 CAN. B. REv. 162, 163-64 (1990).

172 Prostitution Reference, [1990] 1 S.C.R. 1123. 
The party raising the constitutional challenge sought to avoid the taint of Lochner's libertarianism and to situate her claim within the privacy limb of substantive due process. The claimant argued by analogy to the professional regulation cases (which had succeeded in the lower courts) that the law violated her right to engage in "a lawful occupation," since the law prohibited solicitation but not prostitution itself. ${ }^{173}$ The attorney general of Canada responded by attempting to recategorize the challenge as one based on economic liberty and expressly invoked the Lochner era. ${ }^{174}$

In his judgment, Justice Lamer rejected the constitutional challenge and engaged in an extensive examination of American constitutional jurisprudence. His first move was to delegitimize the claimant's arguments by characterizing them as claims of economic liberty, thus tying them directly to the economic limb of the substantive due process cases of the Lochner era and rejecting the claimant's attempts at strategic redescription. ${ }^{175}$ Justice Lamer's next move was to discuss the Court-packing crisis:

The onset of the Depression and President Roosevelt's New Deal initiatives caused a confrontation between the notion of "economic liberty" and the needs of a modern regulatory state. Beginning in 1935 the U.S. Supreme Court rendered a number of decisions invalidating New Deal legislation... What ensued was the so-called "Court Crisis" in which President Roosevelt proposed a court reorganization plan. The plan was never put into effect. Significantly, however, the court overruled its decisions... and adopted a more deferential approach to cases of state regulation of "economic liberty."176

Justice Lamer concluded that the liberty interest was limited to physical liberty and did not extend any further. ${ }^{177}$ The point of Justice Lamer's excursus into

${ }^{173}$ Factum of the Appellant. 13-15.

${ }^{174}$ Factum of the Attorney General of Canada, 19.

${ }^{175}$ Prostitution Reference. [1990] 1 S.C.R. 1123. Justice Lamer observed that "[i]t should not be overlooked. however, that the American experience with 'economic liberty' jurisprudence in particular, has been controversial throughout its history." Id, at 1164. He then proceeded to list the most infamous holdings of the Lochner Court-Allgeyer v. Louisiana. 165 U.S. 578 (1897); Lochner v. New York, 198 U.S. 45 (1905); Adair v. United States, 208 U.S. 161 (1908); Coppage v. Kansas, 236 U.S. 1 (1915); Adkins v. Children's Hospital of the District of Columbia, 261 U.S. 525 (1923)describing them as cases in which "the U.S. Supreme Court invalidated many regulatory measures on the grounds that they intruded upon liberty of contract and property rights." Id. at $\mathbf{1 1 6 5 .}$

${ }^{176}$ Id. at 1165. Lamer wrote: "All of this is to emphasize the difficulties that the United States Supreme Court has faced in dealing with the concept of 'economic liberty' as a constitutionally protected freedom, and how much the American experience is linked to its particular historical record and social context." Id. at 1165-66.

${ }^{177}$ Id. at 1173-74. The majority declined to address this issue, stating that "this case does not provide the appropriate forum for deciding whether 'liberty' or 'security of the person' could ever 
American constitutional history was to counsel extreme caution before importing the economic liberty jurisprudence into Canadian constitutional doctrine. ${ }^{178}$ It is significant that Justice Lamer discussed the danger that Lochner posed to the very institution of judicial review itself. Presumably, Justice Lamer feared that if the Canadian courts became mired in a similar controversy, the legitimacy of their constitutionally entrenched role as enforcers of the Charter could be jeopardized. This fear has been invoked by academic commentators, as well, in order to dissuade the courts from accepting Lochner-style claims. Commenting on a threatened lawsuit against the prohibition on physicians charging patients directly for additional amounts above the rates set by a provincial health insurance plan, on the ground that the law violated section 7 for infringing upon economic liberty, constitutional scholars Allan Hutchinson and Andrew Petter wrote that "[w]e hope it will not take a similar crisis in Canada to convince our courts" to reject the claim. ${ }^{179}$

Attempts to protect economic liberty by means of section 7 have continued. In one case, a challenge was brought against disciplinary proceedings for lawyers on the basis that the right to practice law fell within the scope of "liberty." ${ }^{180}$ Although the Court resolved the case without reaching this issue, interveners opposed to the challenge linked the claim to Lochner-era substantive due process. The attorney general of Quebec, for example, noted that the Fifth and Fourteenth amendments "were interpreted, during a certain era, as protecting a range of commercial activities from government regulation.... Accordingly, a number of laws of a regulatory nature were invalidated..."181 In a later case, the Court summarily dismissed a section 7 challenge to a provincial law restricting the right to practice accounting to persons licensed by a provincial regulatory authority. ${ }^{182}$ One intervener opposing the challenge submitted that the claimants "invite the Court to read into s. 7 a concept of 'economic liberty' similar to that which led the Supreme Court of the United States into the disastrous and now discredited line of cases descending from Lochner v. New York." ${ }^{183}$ Most recently, the respondent in a case of sexual

apply to any interest with an economic. commercial or property component." Id. at $1140-41$ (emphasis in original).

${ }^{178}$ Id. at $1165-66$.

179 Allan Hutchinson \& Andrew Petter. Charter's Core Values Don't Belong to Property Owners, CaN. L., Sept. 1986, at 23, 42 (1986).

${ }^{180}$ Peariman v. Manitoba Law Society Judicial Committee, [1991] 2 S.C.R. 869 (Can.).

${ }^{181}$ Factum of the Attorney General of Quebec. शा 15-16 (translated from original French). See also Factum of the Attorney General of Ontario, ff 36-37; Factum of the Attorney General of Saskatchewan, \15.

182 Walker v. Prince Edward Island, [1995] 2 S.C.R. 407 (Can.).

${ }^{183}$ Factum of the Institute of Chartered Accountants of Prince Edward Island. I 39. See also Factum of the Respondent Government of Prince Edward Island, ๆ 89; Factum of the Attorney 
harassment alleged that the stigma and stress resulting from a lengthy delay in processing the complaint amounted to a deprivation of "liberty." 184 The attorney general of Ontario filed a factum in which it accused the respondent of seeking ultimately to protect economic rights (e.g., present and future prospects of employment) through section 7, and warned the Court "to avoid the controversy that plagued the U.S. Supreme Court during the infamous Lochner era and to avoid deciding matters of general public policy." 185

Moreover, Lochner has been invoked by litigants in Charter cases outside the section 7 context in order to taint other constitutional claims with the brush of economic libertarianism. In its submissions to the Court in the first case on commercial expression, ${ }^{186}$ the attorney general of Quebec argued that such speech should be excluded entirely from the ambit of Charter protection, and that American jurisprudence on commercial expression was to be rejected. because it amounted to the revival of "a now discredited American doctrine believed to have been buried nearly fifty years ago, which was called 'substantive economic due process.' "187 Another example of the invocation of Lochner arose in a challenge to the restriction imposed by an agricultural marketing regime on interprovincial trade in goods, brought under the rubric of the Charter's mobility rights provision. ${ }^{188}$ Two public interest organizations opposed to the challenge argued that accepting the claim raised "the spectre of the so-called Lochner era in the United States, when the U.S. Supreme Court used an expansive interpretation of the U.S. Constitution to protect freedom to contract and property rights," which was "disastrous for government regulation aimed at protecting the public from the destructive tendencies of corporations and the free market." 189

In contrast to the Court's clear rejection of Lochner's economic libertarianism, the question of whether the liberty interest extends to privacy and

General of Quebec, I 54; Factum of the Attorney General of Manitoba, In 30-31; Factum of the Attorney General of Saskatchewan, 123 . A submission supporting the claim sought to disentangle it from the collapse of Lochner-era jurisprudence. Factum of the Certified General Accountants Association of Ontario, I 30.

${ }^{184}$ Blencoe v. British Columbia (Human Rights Commission), [2000] 2 S.C.R. 307 (Can.).

${ }^{185}$ Factum of the Attorney General of Ontario, $\ 42$.

${ }^{186}$ Ford v. Quebec (Attorney General), [1988] 2 S.C.R. 712 (Can.).

${ }^{187}$ Factum of the Attorney General of Quebec, para. 75 (translated from French). The factum also adopted the antiactivist reading of Lochner, by arguing that according constitutional protection to commercial expression would interpret the Charter "as if it implied a particular economic theory which the courts have to follow" when in fact there is "no room for courts to substitute their judgment for that of the legislator." since "in economic matters the Constitution is neutral." Id. at paras. 75 and 79 (translated from original French).

${ }^{188}$ Canadian Egg Marketing Agency v. Richardson. [1998] 3 S.C.R. 157 (Can.).

${ }^{189}$ Factum of the Council of Canadians and the Sierra Legal Defence Fund Society. ๆ 26. 
decisional autonomy has deeply divided the Court. This raises difficult questions regarding what precise lessons the Court has drawn from the Lochner era, and, more fundamentally, the meaning of Lochner in the Canadian constitutional imagination-that is, whether the libertarian or the activist reading of Lochner has taken hold. These cleavages first appeared in a challenge to Canada's federal abortion law. ${ }^{190}$ A plurality of the Court resolved the appeal on procedural grounds, a minimalist approach that avoided the question of whether the liberty interest encompassed a right to reproductive choice. But Justice Wilson squarely addressed the substantive issue and invoked the noneconomic substantive due process jurisprudence as an aid to construing section 7. She interpreted liberty as encompassing "a degree of autonomy in making decisions of fundamental personal importance," a position that "is consistent with the American jurisprudence on the subject." ${ }^{191}$ Instead of distinguishing Roe, or even acknowledging the controversy that surrounds it, she applied it directly, holding that the liberty interest encompassed the right of a woman to terminate her pregnancy. Justice Wilson's judgment met with a sharp rebuke in the dissenting judgment of Justice McIntytre, in which he accused her of judicial legislation. Echoing the critique of Lochner as activist. Justice McIntyre stated that it was "not for the Court to substitute its own views on the merits of a given question for those of Parliament" and that courts should not interpret the Charter to give effect "to the idiosyncratic view of the judge who is writing." 192 To make this point, he relied directly on the authority of Justice Holmes, quoting from his dissent in the Lochner-era case of Tyson \& Bro.-United Theatre Ticket Offices, Inc. v. Banton ${ }^{193}$ and remarking of that dissent that, "although written in the American context, the principle stated [by Holmes] is equally applicable in Canada." 194

A majority of the justices declined to engage in this debate, leaving unresolved the status of Lochner in the Canadian constitutional imagination. But matters later came to a head in a challenge to a statute authorizing a child protection agency to consent to a life-saving blood transfusion on behalf of an

${ }^{190}$ R. v. Morgentaler, [1988] 1 S.C.R. 30 (Can.).

${ }^{191}$ Id. at 166,167 . She then traced the growth of the right to privacy, from its origins in Meyer v. Nebraska. 262 U.S. 390 (1923) and another Lochner-era case. Pierce v. Society of Sisters, 268 U.S. 510 (1925), to its revival in Griswold v. Connecticut, 381 U.S. 479 (1965) and Roe v. Wade, 410 U.S. 113 (1973).

${ }^{192}$ Morgentaler, [1988] 1 S.C.R. at 138, 140.

193273 U.S. 418, 445-47 (1927), where Justice Holmes stated, "I think the proper course is to recognize that a state legislature can do whatever it sees fit to do unless it is restrained by some express prohibition in the Constitution of the United States or of the State, and that Courts should be careful not to extend such prohibitions beyond their obvious meaning by reading into them conceptions of public policy that the particular Court may happen to entertain."

${ }^{194}$ Morgentaler, [1988] 1 S.C.R. at 139. 
infant in contravention of the religious beliefs of that infant's parents. ${ }^{195}$ Speaking for a plurality of the Court. Justice La Forest held that "liberty" encompassed the right of individuals to make decisions of "fundamental personal importance," 196 and that this liberty encompassed the right of parents to make medical decisions for their children. Far from distinguishing Lochnerera case law, the plurality actually relied on two cases from the period, ${ }^{197}$ which immediately raised the question of the status of Lochner itself. Justice La Forest's answer was to note that "[ $t$ ]hose two cases have survived the Lochner era, a much criticized period in which the Supreme Court engaged in substantive review of many economic and social statutes," 198 a line of argument that presumably rejected Lochner's libertarianism but endorsed the use of substantive due process with respect to noneconomic interests.

This characterization of the implications of the plurality judgment was pointed out by (then) Chief Justice Lamer, who concurred in the result but for different reasons. Reiterating his strongly held views that the liberty interest was limited to physical liberty, and that American jurisprudence should not be used as a positive guide to the interpretation of section 7, Chief Justice Lamer raised the fear that Justice La Forest's reasoning would "Lochnerize" the Charter. He noted that "a large proportion of the legislative provisions [currently] in force could be challenged on the ground that they infringe the liberty guaranteed by s. 7 of the Charter," 199 and, in language reminiscent of Holmes's dissent in Lochner, he posed the problem as follows:

We must keep in mind, first, that what may be important and fundamental to one person may very well not be to another, including the judge who hears the case, and second, that by adopting this approach the judiciary would inevitably be legislating, when this is not its function. ${ }^{200}$

In other words, Chief Justice Lamer feared that such a broad and opentextured interpretation of liberty under section 7 would open up the door to judges substituting their views for that of the legislature, not on the basis of constitutional principle, but on the basis of their policy preferences. Thus, in contrast to his decision in Prostitution Reference, but like his judgment in B.C. Motor Vehicle Reference, Chief Justice Lamer operated within a conception of the Lochner era that equated that era with judicial activism.

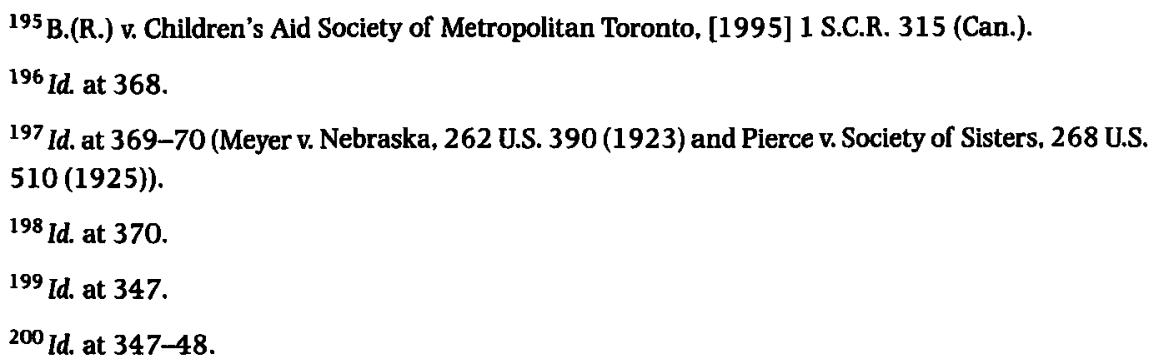




\subsection{Lochner and the legislative override}

Another aspect of the Charter that has prompted constitutional actors to grapple with Lochner's legacy is the legislative override, also referred to as the non obstante or "notwithstanding" mechanism. ${ }^{201}$ The legislative override is the distinctive Canadian contribution to the countermajoritarian dilemma and has generated considerable comparative interest. By offering an alternative set of institutional arrangements to Marbury-esque judicial supremacy, the override strikes a different balance between judicial review and legislative sovereignty. The override allows provincial legislatures and the federal Parliament to enact laws that would otherwise be unconstitutional because they unjustifiably limit certain Charter rights. Declarations issued pursuant to the override are effective for up to five years but can be renewed. The list of rights subject to the override is quite broad and encompasses the "fundamental freedoms" (religion, expression, assembly, and association), the so-called "legal rights" (i.e., rights attaching to persons in their dealings with the criminal justice system), and the right to equality. However, a number of important rights are beyond the override's scope, including the "democratic rights" (e.g., the right to vote), the "mobility rights," and the minority-language rights that were so central to the Charter project for Trudeau.

Other than these restrictions on the range of rights to which the override applies, the text of the override clause contains no substantive limits on its use. This led some scholars to propose that declarations issued pursuant to the override would be subject to some sort of judicial review, ${ }^{202}$ a suggestion summarily rejected by the Supreme Court. ${ }^{203}$ The override's requirements of form have been given a generous interpretation that does not significantly constrain their use. ${ }^{204}$ Furthermore, despite suggestions that the override should be used only after and in response to judicial findings of unconstitutionality-i.e., that it function as a suspensive veto-the text of the provision does not itself

\footnotetext{
${ }^{201}$ Charter, supra note $10, \S 33$.

${ }^{202}$ Daniel J. Arbess, Limitations on Legislative Override under the Canadian Charter of Rights and Freedoms: A Matter of Balancing Values, 21 Oscoode HaLL L.J. 113 (1983); Brian Slattery, A Theory of the Charter, 25 Oscoode HaLL L.J. 701 (1987).

${ }^{203}$ Ford v. Quebec (Attorney General), [1988] 2 S.C.R. 712 (Can.).

${ }^{204}$ Section 33 provides that "notwithstanding" declarations must "expressly declare" that the override is being invoked; the declarations must be contained in "an Act of Parliament or of the legislature"; and that declarations must state "that the Act or a provision thereof shall operate notwithstanding a provision included in section 2 or sections 7 to 15 of the Charter." But the Court has rejected constitutional challenges to boilerplate declarations that neither identified nor spelled out the specific rights that were being overridden, the insertion of this boilerplate declaration in a large mass of previously enacted legislation through a single omnibus statute, and the inclusion of this declaration in all subsequent legislation through a single law enacted in advance. Ford. [1988] 2 S.C.R. 712. For a full discussion. see Lorraine E. Weinrib, Learning to Live With the Override, 35 MCGmL L.J. 541 (1990).
} 
impose such a requirement. Accordingly, it can and has been used preemptively to immunize legislation from Charter scrutiny. ${ }^{205}$

The genealogy of the override is unclear, in large part because the course of federal-provincial negotiations precluded the development of a detailed written record. ${ }^{206}$ Federal-provincial negotiations collapsed in the fall of 1980 , with the federal government opting to proceed unilaterally in securing the adoption of a Charter without a legislative override. As a direct consequence,

${ }^{205}$ For a comprehensive review of this legislation, see Tsvi Kahana. The Notwithstanding Mechanism and Public Discussion: Lessons from the Ignored Practice of Section 33 of the Charter. 44 Can. Pub. Admin. 255 (2001).

${ }^{206}$ The most widely popularized account is offered by Canadian expatriate and legal scholar Paul Weiler, who takes credit for having "launched" the notion of the legislative override in a public lecture in 1979. Paul C. Weiler. Rights and Judges in a Democracy: A New Canadian Version. 18 U. MicH. J.L. REFORM 51, 79-80 (1984) [hereinafter Rights and Judges in a Democracy]. This lecture was subsequently published. Paul C. Weiler, Of Judges and Rights, or Should Canada Have a Constitutional Bill of Rights? 60 DALHOUSE REv. 205 (1980). According to Weiler, his lecture "was the only written brief" in favor of a legislative override, but (save for a conversation with the premier of Saskatchewan) his "argument remained in academic obscurity" until September 1981, when the Supreme Court of Canada injected new life into failed constitutional negotiations. Weiler. Rights and Judges in a Democracy, supra note 206, at 80 n.97. Weiler states that prior to the final round of negotiations in November 1981, he "spoke personally" to various senior civil servants and public officials, who then negotiated a charter with the override. Id. Although there is some independent support for Weiler's description of his own role (SHEPPARD \& VALPY, supra note 106, at 259), his claim of primary authorship is questionable. Peter Lougheed. premier of Alberta during the negotiations, stated in the Alberta legislature on the day immediately following the successful conclusion of negotiations that he had raised the idea of the override in discussions with Trudeau in February 1979. Alberta Hansard 1502 (Nov. 6. 1981). Many years later, in a public lecture, Lougheed put the date of his support of the override at September 1980. Peter Lougheed. Why a Notwithstanding Clause? 6 PoINTS of VIEW 1, 2 (1998). A Government of Alberta position paper. dated October 1978, clearly proposes the idea of an override, lending support to Lougheed's claims. Alberta, Harmony in Diversity: A New Federalism for CaNada 22 (Government of Alberta 1978). Published accounts of the negotiations confirm that Alberta lobbied actively for the override, as did Saskatchewan. SHEPPARD \& VALPY, supra note 106; ROMANOW ET AL., supra note 106, at 188-215; Janet L. Hiebert, Limiting Rights: The Dilemma of Judicial Revirw $163 \mathrm{n.43}$ (Univ. of Toronto Press 1996). Finally, Howard Leeson. Saskatchewan's deputy minister of intergovernmental affairs at the time, has recently provided documentary evidence that the override was being discussed by federal and provincial governments as early as December 1978, well before Weiler's lecture. Howard Leeson, Section 33. The Notwithstanding Clause: A Paper Tiger? 6 CHolces, June 2000, at 1, 9-10 (2000) (quoting a Saskatchewan government briefing note). Indeed, a federal draft of the Charter dated January 8, 1979, contains proposed language for the legislative override. Federal Government Discussion Draft. Jan. 8, 1979, $\$ 131(5)(b)$, reprinted in 2 BAYEFSKY, supra note 83 , at 547 . Weiler. Lougheed, and Neeson agree that the leading model for the override was the non obstante provision in the Canadian Bill of Rights. Section 2 provides that "[e]very law of Canada shall, unless expressly declared by an Act of the Parliament of Canada that it shall operate notwithstanding the Canadian Bill of Rights, be so construed and applied as not to abrogate, abridge. or infringe or to authorize the abrogation, abridgment, or infringement of any of the rights or freedoms herein recognized and declared...." Canadian Bill of Rights, ch. 44, 1960 S.C. 519 (Can.), reprinted in R.S.C. app. III (1985) (Can.). 
the Hays-Joyal Committee did not discuss the override at all. The override was added to the Charter during the final round of constitutional negotiations in November 1981. However, these were closed-door discussions, and the final text of the Charter was sent to Westminister for adoption without any hearings before a parliamentary committee in Canada.

However, useful information can be gleaned from some of the statements offered by key negotiators in the immediate wake of the successful conclusion of negotiations. On the one hand, there were those who clearly viewed the override as a compromise born of political expediency, rather than high constitutional principle. The sense was that the override was the price to be paid for near-unanimous provincial agreement, as opposed to an important innovation in constitutional design. A charter with an override was better than no charter at all. Premier Bill Davis of Ontario, for example, stated that "[w]e are not totally satisfied, yet... it was better to have something less than perfection." 207 This view was echoed by Trudeau. ${ }^{208}$ But other participants described the override not as part of a second-best solution but as preferable to a fully entrenched bill of rights with no possibility for legislative response. For example, the federal minister of justice. Jean Chrétien, stated in the House of Commons that the override "is a safety valve to correct absurd situations without going through the difficulty of obtaining constitutional amendments."209 Premier Allan Blakeney of Saskatchewan also described the override "as a constitutional escape valve," 210 and Ontario's minister of intergovernmental affairs referred to the override as "an added protection" that enables legislatures "to correct some wrong ... brought about by some judicial decision."211

The idea that legislatures should possess a mechanism for overturning court judgments harkens back to the interinstitutional conflict sparked by the New Deal that marked the end of the Lochner era. Not surprisingly then. Lochner has been invoked by defenders of the override, but for two different purposes. First, Lochner has been used to specify the dangers of judicial review-i.e., what kinds of errors might prompt the legitimate use of the override. Among the provincial premiers, the most articulate opponent of the

207127 OnTario Legislative Assembly Debates 4556 (Dec. 11, 1981).

${ }^{208}$ House of COMmons DeBates 13439 (Nov. 27, 1981) ("This did mean on this side giving up quite a bit. It meant telling the premiers: We will give in to you when you want a non obstante clause..."). And the momentum that had developed for the entrenchment of constitutional rights meant that it was just a matter of time before this imperfection would be narrowed and perhaps removed through constitutional amendment. As Davis said, "it will not be many years before the fundamental rights will be part of the entrenched part of the Charter" (i.e., not subject to the override). LEGISLATIVE ASSEMBLy OF ONTARIo DebatES 3265 (Nov. 6, 1981).

${ }^{209}$ House OF COMmons DeBATES 13043 (Nov. 20. 1981).

${ }^{210}$ Debates and Proceidings of the Legislative Assembly of Saskatchewan 401 (Dec. 9. 1981); id. at 134 (Dec. 2. 1981).

211119 Ontario LegiSlative Assembly Debates 4269 (Dec. 7, 1981). 
Charter was Blakeney, a social democrat. His basic fear, as some commentators have described it, was that "[e]ntrenchment would transfer political power to the courts, which were generally conservative and would oppose redistribution of power and wealth in society." ${ }^{212}$ Blakeney argued that "[n]o democratic socialist... should voluntarily hand power from the political forum, where the policies of the majority find expression, to the judicial forum." ${ }^{213}$ Blakeney's opposition to the Charter drew on a number of sources. One was the left's traditional suspicion of Canadian courts because of their historical antipathy toward unions. Another was the comparative experience of the United States. Blakeney testified before the Special Joint Senate and House Committee that section 7 posed the risk of courts striking down socioeconomic legislation in the manner of the Lochner Court. ${ }^{214}$ Blakeney's attorney general, Roy Romanow, also wrote that the experience of the Lochner Court underlay Blakeney's support for the override, in order to protect the possibility of social democratic public policies. ${ }^{215}$ The leading academic defender of the override, Peter Russell, expressed the same view, describing Lochner as the paradigmatic case of judicial error:

For anyone familiar with the history of judicial review in the United States... it is difficult to believe in the infallibility of judges. In American history, the decisions of the Supreme Court in Lochner and other early twentieth century cases denying state legislatures the power to ensure vulnerable workers decent conditions of employment are reminders of the injustice and harm than can flow from judicial decisions interpreting constitutional guarantees. ${ }^{216}$

David Schneiderman makes the same point, arguing that the override "would have been valuable" during the Lochner era, because "the judiciary was insufficiently attentive to the needs of society and the demands made upon the government to counteract the force of the market."217

\footnotetext{
212 ROMANOW ET AL., supra note 106, at 110.

${ }^{213} \mathrm{Id}$.

${ }^{214}$ ShEPPARD \& VALPY, supra note 106, at 145 (describing Blakeney's written submissions to the Hays-Joyal Committee).

${ }^{215}$ Roy Romanow, "Reworking the Miracle": The Constitutional Accord 1981, 8 QUEEN's L.J. 74, 92-93 (1982-83) [hereinafter Reworking the Miracle]. After the agreement on the text of the Charter, Blakeney gave mandatory retirement laws and legislatively mandated union shop agreements as two examples of laws that could be struck down by the Charter. DEBATES AND PROCEBDINGS OF THE LEGISLATIVE ASSEMBLY OF SASKATCHEWAN 400 (Dec. 9, 1981). It is worth noting that Blakeney testified in favor of an override provision before the Hays-Joyal Committee in December 1980. 30 Hays-Joyal Commttre Minutes of Prockedings, supra note 92, at 39 (Dec. 19. 1980).
}

216 Peter H. Russell, Standing Up for Notwithstanding. 29 ALTA. L. Rev. 293. 297-98 (1991).

${ }^{217}$ David Schneiderman, Prologue, in Lougheed, supra note 206. at iii-iv. 
Second, proponents of the override have invoked Lochner not to illustrate the sorts of laws the override could legitimately be used to defend but to suggest that it is the best sort of institutional response to deeply controversial judicial decisions. To some extent, this argument is in tension with the first invocation of Lochner, because it concedes that in conflicts between legislatures and courts, legislatures will ultimately prevail, echoing Robert Dahl's famous argument. ${ }^{218}$ For its proponents, the override has significant advantages over the alternative-the power to make judicial appointments-that lay at the heart of the New Deal crisis. The concern here is one of legitimacy, and the comparison with the Court-packing plan is direct. Peter Lougheed, premier of Alberta during the negotiations, writes:

The most familiar example of an attempt to change the direction of the Court's decisions by using the appointment power is found in the "New Deal" crisis of the 1930s, where President Roosevelt wanted to increase the size of the Court in order to appoint judges who would support his "New Deal" legislation.... In Canada, the entrenchment of section 33 [the override] appears to prevent the need to abuse the judicial appointment process...219

Peter Russell shares Lougheed's assessment, and adds "court-bashing" to the menu of undesirable options:
Absent a Canadian-style legislative override, court-packing or court- bashing are the devices to which democratic leaders are most likely to resort when faced with judicial interpretations of the constitution they consider to be seriously unjust and harmful. These devices may yield rel- atively quick results as was the case with Roosevelt's threat to pack the U.S. Supreme Court.... [C]ourt-packing or court-bashing, involving as they do the application of raw majoritarian power to the judicial branch, would seem less appropriate devices than legislative debate and discus- sion for challenging judicial decisions. ${ }^{220}$

In the most recent defense of the override, Kent Roach has made the same point, highlighting that the notwithstanding mechanism is "much less difficult and dangerous" than the Court-packing threatened during the New Deal. $^{221}$

\footnotetext{
${ }^{218}$ Robert A. Dahl, Decision-Making in a Democracy: The Supreme Court as a National Policy-Maker, 6 J. PuB. L. 279 (1957).

${ }^{219}$ Lougheed, supra note 206 , at 12 . The other alternative Lougheed considers is to disobey Supreme Court judgments, citing the refusal of Lincoln to enforce "a decision by the Supreme Court in a case involving civil rights" (Id. at 12). He disapproves of this mechanism as well.

${ }^{220}$ Russell, supra note 216 , at 298.

${ }^{221}$ Kent Roach, The Supreme Court on Trial: Judicial Activism or Democratic Dialogue 249 (Irwin Law 2001).
} 
To its defenders, the override serves as an outlet, channeling potentially dangerous and destructive responses to judicial decisions into legislative forums where brute power is tempered by the demands of public justification and the procedures of parliamentary democracy. Moreover, it is a more precise instrument than the alternatives, since it permits legislatures to address specific rulings, unlike the indirect and blunt mechanisms of personnel change or political pressure. Finally, unlike court-packing (and court-bashing), the override enables a response to courts that does not undermine their independence and impartiality, thereby protecting their institutional legitimacy. It is, therefore, somewhat ironic, as Bruce Ackerman has noted, that a constitutional amendment creating a congressional override was advocated by New Dealers who were opposed to the Court-packing plan for the very same reasons put forth by proponents of the override. ${ }^{222}$

\section{Conclusion}

The use of Lochner discourse in the Canadian constitutional system offers a number of lessons for both the study and practice of comparative constitutional law. But these lessons are best approached through a broader discussion of the challenge that the globalization of the practice of modern constitutionalism poses to traditional conceptions of constitutionalism and relatedly, the very point and structure of the comparative constitutional enterprise. The increased migration of constitutional forms stands at odds with one of the dominant understandings of constitutionalism-that the constitution of a nation emerges from, embodies, and aspires to sustain or respond to a nation's particular national circumstances, most centrally, its history and political culture. Indeed, for some countries, particularly those with a diverse citizenry, lacking a prior or prepolitical bond of ethnicity, religion, or race, constitutions are an important component of national identity and reflect one way in which those nations view themselves as distinct from others.

On this account-one of legal particularism-constitutions should only be framed and interpreted by reference to sources internal to a national legal system. The use of comparative materials is, at best, a curiosity of no practical relevance and of marginal academic importance, and, at worst, a form of legal imperialism. The American constitutional system is, perhaps, the most prominent example of a constitutional regime that is steadfast in its commitment to legal particularism, a stance all the more striking in light of the increasingly comparative outlook of other jurisdictions. Justice Antonin Scalia's well-known admonition that "comparative analysis [is] inappropriate to the

2222 ackerman, We tHe People, Transformations, supra note 16, at 321-24. See also Gerald V. La Forest, The Canadian Charter of Rights and Freedoms: An Overview, 61 CAN. B. REv. 19, 25-6 (1983) (explaining, with reference to the United States, how legislatures ultimately prevail over courts. but that the override offers a preferable mechanism for allowing legislatures to have the last word). 
task of interpreting a constitution" is representative of the mainstream of American judicial practice. ${ }^{223}$ And American constitutional practice is tracked by American constitutional theorists, who tend to rely overwhelmingly on local or particular sources-e.g., the origins of the framers, American political traditions-as aids to constitutional interpretation, suggesting that those sources secure the legitimacy of judicial review, even if their actual use is only rhetorical. Bruce Ackerman's memorable call for an indigenous approach to constitutional theory, "[t]o discover the Constitution ... without the assistance of guides imported from another time and place," ${ }^{224}$ reflects the mind-set of American constitutional thought.

Committed particularists hold the view that no country can learn from any other. However, legal particularism can be juxtaposed to a radically different stance on the value of comparative constitutional law. To some, certain constitutional experiences exert a hegemonic influence over domestic constitutionalism in other jurisdictions, structuring the very terms of debate, and, if not dictating, at least pointing to the path that constitutional framings and interpretations should take. And the dominant constitutional model that many commentators point to, almost invariably, is that of the United States. This has led some American commentators to hold that while America has little to learn from comparative constitutional experience, foreign jurisdictions can learn a great deal from the United States. Accordingly, the direction of comparative insight flows from America outward, and not the other way around. Steven Calabresi's statement that "[ $t$ ]he rest of the world is quite rightly impressed with us, and it is thus no accident that the United States of America has become the biggest single exporter of public law in the history of humankind" is perhaps the most extraordinary example of this kind of conceit. ${ }^{225}$ Even the elder

\begin{abstract}
${ }^{223}$ To be sure, David Fontana has documented many instances in which justices of the U.S. Supreme Court have drawn support from foreign legislative practice, to hold either that certain policies are constitutionally prohibited (Stanford v. Kentucky, 492 U.S. 361 (1989), whether criminal sanctions contravene norms so "implicit in the concept of ordered liberty" that they are "cruel and unusual punishment" under the Eighth Amendment) or conversely, that certain policies are constitutionally permitted (McGowan v. Maryland, 366 U.S. 420 (1961) (Sunday closing läws)). David Fontana, Refined Comparativism in Constitutional Law, 49 UCLA L. REv. 539, 544-49, 574-91 (2001). However, to describe these references as invocations of comparative constitutional law is somewhat misleading, for the fact that a policy does or does not exist in a foreign constitutional order is of little relevance if that order lacks restraints analogous to those under consideration. Indeed, it is striking that the link between foreign legislative experience and foreign constitutional text and interpretation is rarely if ever made by the U.S. Supreme Court, a fact that casts real doubt on the claim that American justices are engaging in comparative constitutional law. This is Vicki Jackson's view. Vicki C. Jackson, Narratives of Federalism: Of Continuities and Comparative Constitutional Experience, 51 DuKE L.J. 223 (2001).
\end{abstract}

2241 Ackerman, We the Prople, Foundations, supra note 16, at 3.

${ }^{225}$ Here is what Steven Calabresi says in full:

[T]he Federalist Constitution has proved to be a brilliant success, which unitary nation states and parliamentary democracies all over the world would do well to copy. I give it most 
Calabresi has referred to the relationship between the American Constitution and the constitutions of other jurisdictions as analogous to that between a "parent" and its "constitutional offspring."226

Lochner discourse poses a challenge to both the particularist and the hegemonic strands of comparative constitutional discourse. To understand why, we need to consider the limitations of both approaches. Legal particularism has come under attack from two sources. One proceeds from the claim that constitutional guarantees are cut from a universal cloth, and that comparative materials are a source of insight into the articulation and application of transcendent legal principles, notwithstanding allegedly superficial differences among constitutional texts. Comparative jurisprudence, for example, serves an evidentiary function, providing valuable articulations of the political theories underlying particular constitutional rights and of how those rights are to be applied in concrete cases. The second response is functionalist and begins from the observation that constitutional analysis often addresses the empirical effects of the constitutional structures and doctrines that are the means for implementing constitutionally mandated ends (e.g., federalism). However, the degree and likelihood of success of these various means are empirical questions that figure legitimately into questions of constitutional choice. The functionalist thesis is that comparative experience assists in constitutional analysis as a source of data. By eschewing comparative investigation, we forsake alternative solutions. Stephen Gardbaum has argued, for example, that there is an emerging model of "Commonwealth Constitutionalism" that at once permits legislatures to have the final say, while allowing courts to scrutinize public policies for compliance with fundamental rights, offering an alternative set of institutional arrangements to the extremes of legislative sovereignty and Marbury-style judicial supremacy. 227

of the credit for the fact that ours is the wealthiest, most technologically advanced, and most socially just society in human history, not to mention the fact that we have with ease become a military superpower.... The rest of the world is quite rightly impressed with us, and it is thus no accident that the United States of America has become the biggest single exporter of public law in the history of humankind. Almost wherever one looks, written constitutions, federalism, separation of powers, bills of rights, and judicial review are on the ascendancy all over the world right now-and for a good reason. They work better than any of the alternatives that have been tried.

Steven G. Calabresi, An Agenda for Constitutional Reform, in ConstTTUTIONAL StUPIDITIES, Constitutional Tragedies 22 (William N. Eskridge \& Sanford Levinson eds., New York Univ. Press 1998).

${ }^{226}$ United States v. Then, 56 F.3d 464, 469 (2d Cir. 1995) (Calabresi, J., concurring). Some American scholars take a very different view. See, e.g. Ackerman, supra note 9.

${ }^{227}$ Stephen Gardbaum, The New Commonwealth Model of Constitutionalism. 49 AM. J. COMP. L. 707 (2001). Doctrinally, Justice Breyer's argument in Printz v. United States, 521 U.S. 898, 976-78 (1997), that the "commandeering" of the officials of the constituent units of federations, such as Germany, Switzerland, and the European Union, to implement federal policies may actually be more rather than less protective of local autonomy, is another example of functional analysis. 
Both the normative and functionalist critiques of legal particularism are deeply controversial. The normative argument runs head-on into cultural relativism, which holds that moral and political values are not universal but are tightly connected to particular cultural contexts. Whatever the merits of this debate, it is fraught with controversy. As a consequence, the legitimacy of universalist modes of comparative constitutional reasoning will constantly be put in question. The functionalist argument encounters difficulty when faced with the objection that the viability of doctrinal or structural transplants is often a function of the "the constitutional and social context" in which they operate, such as the design of other legal institutions and the facts of political sociology. ${ }^{228}$ On the latter point, Mark Tushnet's analysis of a potential constitutional transplant-the notion of legislator standing, well established in Germany and France but constitutionally controversial in the United States ${ }^{229}$-is telling. ${ }^{230}$ Tushnet clearly favors this doctrinal development in the United States, noting that it has not disrupted the relationship between the executive and legislative branches in France and Germany. But he himself acknowledges that "the effects of legislator standing may differ in systems with centralized rather than dispersed judicial review, in those with and without a well-organized public interest bar, and in those with parliamentary rather than divided powers political systems," ${ }^{231}$ meaning that "[a] functionalist analysis of comparative experience with legislator standing allows us to draw some modest conclusions," 232 but not much more.

Shifting the viewfinder to Canada enriches and recasts the terms of debate over the use of comparative constitutional materials. By focusing on a jurisdiction where comparativism is a widespread and well-established part of constitutional discourse, Lochner discourse yields important insights otherwise inaccessible when relying on jurisdictions notorious for their resistance to comparative legal sources. This is the principal limitation of recent American contributions to the critical literature, ${ }^{233}$ which have focused on American materials instead of concrete examples providing a richer picture of the phenomenology of comparative constitutional law, and, as a consequence, offer little basis for understanding the practice of comparative constitutional argumentation.

\footnotetext{
${ }^{228}$ Matthew D. Adler, Can Constitutional Borrowing Be Justified? A Comment on Tushnet, 1 U. PA. J. CONST. L. 350, 356 (1998).

${ }^{229}$ Raines v. Byrd, 521 U.S. 811 (1997).

${ }^{230}$ Mark Tushnet, Returning with Interest: Observations on Some Putative Benefits on Studying Comparative Constitutional Law. 1 U. PA. J. CoNsT. L. 325 (1998).

${ }^{231}$ Id. at 348.

${ }^{232}$ Id.

${ }^{233}$ Tushnet, supra note 230; Fontana, supra note 223: Jackson, supra note 223.
} 
What lessons does Lochner discourse hold for students of comparative constitutional law? Most fundamentally, Lochner discourse illustrates how comparative materials can be used in a way that is neither particularist nor universalist, and thus sets to one side a debate that has become deadlocked, futile, and sterile. The starting point is the recognition that a claim to constitutional distinctiveness is inherently relative; a constitution is only unique by comparison with others which may lack some feature that constitution possesses. Accordingly, a keener awareness and a better understanding of difference can be achieved through a process of comparison. I term this use of comparative constitutional materials-as a way of facilitating a greater understanding of one's own legal system-dialogical. ${ }^{234}$ Under the dialogical model, constitutional actors engage with comparative constitutional materials, not with a primary goal of apprehending all their details with exacting accuracy but, instead, for the purpose of identifying the normative and factual assumptions upon which they are based, or the lessons that have been ascribed to them in the constitutional discourse of that jurisdiction. Canadian constitutional actors, for example, have engaged in discussion of the Lochner era not to better understand the finer aspects of the Lochner Court's holdings but to locate within that era more-abstract conceptions of the appropriate relationship between state and market, lessons regarding the nature of the judicial role, and the institutional costs of sustained and prolonged conflict between courts and democratically accountable institutions.

At the end of the day, under the dialogical model, the engagement with comparative materials facilitates constitutional choice, because it clarifies the implications of certain institutional, textual, and interpretive options. And it does this for a whole range of constitutional actors, each involved at various stages in the life cycle of a constitution-constitutional framers, courts, litigants, and members of the public. For example, in the Canadian constitutional system, the Lochner era has suggested the path not to be taken during both the framing and the interpretation of the Charter. Specific features of the Charter-the omission of property interests, the choice of "fundamental justice" over "due process," the inclusion of the legislative override-can be understood as deliberate choices meant to preclude the emergence of various aspects of Lochner's legacy in Canada. And in the subsequent interpretation of section 7, the imperative of avoiding Lochner has been a driving force. The dialogical model refutes the particularist claim that there is nothing to be gained from an examination of comparative constitutional materials. As Lochner

\footnotetext{
${ }^{234}$ Vicki Jackson has expressed a similar view, writing that "[e]ven if the reasoning of a foreign court ultimately is rejected, explaining why it is inapplicable or wrong could improve the quality of the Court's reasoning, making its choices more clear to the audience of lawyers, lower courts. legislators, and citizens. The transnational discourse of constitutional decisionmaking provides a broader arena for this kind of constitutional accountability conversation." Jackson, supra note 223, at 260-61.
} 
discourse illustrates, an engagement with comparative experience may sharpen constitutional actors' awareness of constitutional difference. Moreover, the dialogical mode of comparative constitutional argumentation does not raise the specter of illegitimacy in the manner that some particularists fear. The reliance on comparative constitutional materials does not necessarily assimilate constitutional actors into a larger transnational conversation about rights, courts, and democracy. A sophisticated and literate comparativism need not be tantamount to the embrace of universalist conceptions of constitutionalism.

The status of the Lochner era in Canadian constitutional thought also serves as an antidote to a narrow functionalism. To be sure, the framing of the override in light of the Court-packing crisis during the New Deal proceeded on the basis of a functional use of comparative constitutional history. But for the most part, rather than providing empirical data for the project of institutional design, the Lochner era looms as a parable or a cautionary tale. Lochner is regarded as a powerful symbol of deep and profound constitutional failure, which transcends the particulars of the individual judgments and interinstitutional conflicts that constituted the Lochner era. The invocation of Lochner operates rhetorically as an epithet, as a signal of potential danger. Indeed, the ongoing citation of Lochner by constitutional negotiators, litigants, and courts to delegitimize constitutional claims bears vivid testimony to its rhetorical power. So, too, do the attempts to redescribe claims to protect economic liberty as a way to avoid the taint of Lochner's libertarianism. To be sure, the rhetorical power of Lochner also speaks to the widespread literacy in American constitutional history and jurisprudence among Canadian constitutional actors-an important component of Canada's constitutional sociology. In this light, references to Lochner that are brief and rather cursory, rather than indicating a lack of familiarity with Lochner should, instead, be understood as the use of a code for a set of constitutional ideas, and a historical episode, that has become part of the intellectual vocabulary of global constitutionalism. ${ }^{235}$

Lochner discourse is a particularly rich interpretive resource for jurisdictions whose experience with constitutionalism is in its preliminary stages. Rather than waiting for a suitable domestic constitutional narrative to unfold, the Lochner era offers a comparative narrative that is ready for the taking. No doubt, this is an important explanation for the prevalence of Lochner discourse in Canada. Although constitutional judicial review on federalism grounds had existed since the mid-nineteenth century under the constitution Act, 1867 , that document contained few entrenched rights. ${ }^{236}$ The absence of domestic

\footnotetext{
${ }^{235}$ For an early example of comparative work that was critical of Lochner and relied on Lochner as a basis for opposing judicial review, see ÉDOUARD LAMBERT, LE GOUVERNEMENT DES JUGES ET LA LUTTE CONTRE LA LÉGISLATION SOCIALE AUX ÉTATS-UNIS: L'EXPÉRIENCE AMERICAINE DU CONTROLE JUDICIAIRE DE LA CONSTTIUTIONNALITE DES LOIS (Marcel Giard \& Cie 1921).
}

${ }^{236}$ Constitution Act, 1867 (U.K.), 30 \& 31 Vict., c. 3, reprinted in R.S.C., app. II, No. 5 (1985). 
precedents provided the opportunity and impetus for the framers of the Charter to turn to the American experience. Similarly, the relentlessly comparative approach to the drafting of the Charter, coupled with the absence of a body of domestic jurisprudence, meant that courts and litigants naturally turned to American constitutional history and jurisprudence to shape the interpretation of the Charter. And again, the widespread literacy in American materials contributed to the willingness of constitutional actors to accept Lochner as a common reference point.

Lochner discourse also illustrates that the negative meanings of comparative constitutional experiences are complex. The three meanings of Lochner require constitutional actors that reject Lochner to clarify which aspect of Lochner's legacy they are rejecting. In the Canadian case, for example, the drafting history of the Charter reveals considerable disagreement over the lessons that the framers drew from Lochner. That disagreement was reflected in the early texts of the Charter, and the supporting documentation and testimony. At best, we can say that the drafters of the Charter decisively rejected Lochner's economic libertarianism. However, they were divided sharply over the lessons they drew from the critique of Lochner's judicial activism, a disagreement that runs through the subsequent jurisprudence and that remains unresolved. It is a testament to the power of Lochner, though, that the participants in this debate invoke different conceptions of anti-Lochnerism. Interestingly, the image of constitutional crisis is largely absent from Canadian constitutional jurisprudence. However, it has been central to the justification of the override. Indeed, the two phenomena may be linked, since the possibility of the override was designed to diminish courts' anxiety about constitutional judicial review (although it is far from clear that the override has had this effect). ${ }^{237}$

Finally, Lochner discourse disrupts the simplistic picture of the hegemonic place of the American constitutional experience in the global constitutional imagination. On the one hand, it is clear that the drama of the Lochner era and the New Deal crisis looms large, occupying a central place in the emerging global constitutional consciousness. Indeed, the fact that the Lochner era is thoroughly discredited within the mainstream of American constitutional thought marks a critical point of convergence. Lochner serves as a negative model both within and outside the United States. But Lochner discourse also demonstrates that the globalization of legal knowledge need not result in the homogenization of political and legal order. The constitutional choices made during the drafting and interpretation of the Charter go far beyond the postLochner settlement in the United States. The Charter excludes the direct protection of economic rights; it was envisioned originally as providing strictly procedural protection under the due process clause; and it contains a safety

${ }^{237}$ Sujit Choudhry, Book Review, 1 INT'L J. CONST. L (I-CON), 379. 385-89 (2003) (reviewing Christopher P. Manfred, Judictal Power and the Charter: Canada and tHe Paradox of Liberal CONSTTTUTIONALISM (2001)) (discussing the override). 
valve that avoids the need to consider changing the composition of the courts to reverse controversial decisions. Lochner discourse accordingly demonstrates that learning across jurisdictions through the use of comparative legal materials can thus provide both the impetus for, and the resources to strengthen, moments of constitutional difference. Legal globalization is not necessarily the handmaiden of legal imperialism. 